\title{
Ávöxtun og áhætta íslenskra lífeyrissjóða 1993-2017
}

\author{
Gylfi Magnússon $^{1}$
}

\begin{abstract}
Ágrip
Í pessari grein er rýnt í ávöxtun samtryggingardeilda íslenskra lífeyrissjóða tímabilið 1993-2017, samtals 25 ár. Greint er frá forsögunni og skrifum annarra í kafla 1, í kafla 2 er aðferðafræði lýst, í kafla 3 birtast helstu tölulegar niðurstöður, í kafla 4 er frekari greining. Tímabilið sem skoðað er ræðst af pví að gögn sem FME hefur gert aðgengileg um einstaka sjóði ná ekki lengra aftur í tímann. Takmörkuð gögn liggja fyrir um ávöxtun fyrstu fjögurra ára pessa tímabils og er pví einkum horft til áranna 1997 til 2017 pótt birt sé ávöxtun fyrir hluta sjóðanna allt aftur til 1993 og jafnframt séu nokkur styttri tímabil sem hefjast eftir 1997 skoðuð. Í ljós kemur að ávöxtun lífeyrissjóða sem heildar hefur verið nokkuð viðunandi petta tímabil, sérstaklega í ljósi hruns fjármálamarkaða, og í takti við pað sem vænta mátti í ljósi pess hvaða eignaflokka sjóðirnir kaupa einkum og hver ávöxtun peirra hefur verið. Meðalraunávöxtun sjóðanna var 3,73\% á ári. Áhættuálag sjóðanna hefur pó verið ekkert p.e. peir hafa tekið verulega áhættu en endað pegar upp er staðið með ávöxtun sem samsvarar nokkurn veginn áhættulausum vöxtum. Pó er verulegur munur milli sjóða. Hann mun hafa áhrif á getu peirra til að greiða lífeyri. Jafnframt er verulegur munur á peim hópum sem greiða í hvern sjóð. Раð mun einnig hafa áhrif á lífeyrisgreiðslur peirra. Pví býr lífeyriskerfið til töluverða óvissu um lífskjör lífeyrispega eftir sjóðum. Hægt væri að gera breytingar á kerfinu sem myndu draga úr áhættu við pað frá sjónarhóli einstakra launpega.
\end{abstract}

\section{Abstract}

This article analyzes the return on investments by mutual insurance pension funds in Iceland in the period 1993-2017. Chapter 1 provides a historical overview and discusses prior research, Chapter 2 provides an overview of the methodology used, Chapter 3 contains the main numerical results and Chapter 4 further analysis. The time period was chosen as the Icelandic Financial Supervisory Authority (FME) has made data available on individual pension funds for all these years. Data for the first 4 years is however limited. Thus, the main focus is on the period 1997-2017. We also analyze returns for various subperiods. The return on the assets of the pension

1 Gylfi Magnússon er dósent í viðskiptafræðideild Háskóla Íslands. Netfang: gylfimag@hi.is. Höfundur er jafnframt formaður bankaráðs Seðlabanka Íslands og formaður endurskoðunarnefndar LSR. Greinin er á ábyrgð höfundar og parf ekki að endurspegla skoðanir pessara stofnana. Höfundur vill pakka Hallgrími Óskarssyni hjá ráđgjafafyrirtækinu Verdicta fyrir samstarf um nýtingu peirra útreikninga sem rannsóknin byggir á og góðar ábendingar og sömuleiðis fjölmörgum starfsmönnum lífeyrissjóða fyrir gagnlegar ábendingar.

This work is licensed under a Creative Commons Attribution 4.0 License.

DOI: https://doi.org/10.24122/tve.a.2018.15.2.8 
funds as a whole has been reasonable in light of the collapse of Iceland's financial market and as can be expected given the yield on the asset classes that the funds mainly invest in. The average annual real return was 3,73\%. Their overall return is quite similar to the risk-free return over the period so they have not benefitted from any risk premium, despite investing to a degree in risky assets. The return across funds varies significantly. This will inevitably affect their ability to provide pensions. In addition, there is a substantial difference in the demographics of the workers behind each fund. This will also affect their ability to pay out pensions. The system thus generates substantial risk for future pensioners, leading to differences in the standard of living that they will be able to afford depending on which fund they have paid into. The structure of the pension system could be changed to address this, substantially reducing the risk facing individual pensioners.

JEL flokkun: J32; G11; G23.

Lykilorð: Lífeyrissjóðir; ávöxtun; áhætta.

Keywords: Pension funds; returns; risk.

\section{Return on assets and risk for Icelandic pension funds 1993-1997}

\section{Inngangur}

\section{1 Íslenska lífeyriskerfið: Forsagan}

Upphaf íslenska lífeyrissjóðakerfisins er almennt rakið til ársins 1969 pótt starfstengdir lífeyrissjóðir hafi verið starfræktir hér á landi allt frá árinu 1921. Árið 1969 var kveðið á um stofnun sjálfstæðra, starfstengdra samtryggingarsjóða í almennum kjarasamningum. Í kjölfarið voru fjölmargir lífeyrissjóðir stofnaðir sem enn starfa eða hafa sameinast sjóðum sem enn starfa. Árið 1974 varð aðild að peim skylda fyrir launpega og árið 1980 fyrir sjálfstætt starfandi. Til að byrja með var almennt einungis greitt iðgjald af dagvinnulaunum. Árið 1986 breyttist pað og var pá ákveðið að greiða iðgjald af heildarlaunum fyrir starfsmenn á almennum vinnumarkaði. Breytingin kom til framkvæmda í áföngum og að fullu frá og með 1990.

Miklar breytingar urðu á íslenska lífeyrissjóðakerfinu á tíunda áratugnum. Almennum lögum um lífeyrissparnað var breytt allmikið undir lok árs 1997 og tóku nýju lögin gildi um mitt næsta ár (Lög um skyldutryggingu lífeyrisréttinda og starfsemi lífeyrissjóða nr. 129/1997 (lífeyrissjóðalögin)). Мeð nýjum lífeyrissjóðalögum var skyldutrygging skilgreind sem m.a. hafði talsverð áhrif á sjóði sem áður höfðu eingöngu starfað sem séreignarsjóðir.

Undir lok áratugarins var að mestu komið pað skipulag á sem enn ríkir. Eru pví sérstaklega birtar tölur um ávöxtun tímabilið 2000-2017. Nokkrir sjóðir gengu í gegnum miklar breytingar á árunum 1997-1999. Eru pví ávöxtunartölur fyrir pað tímabil ekki að fullu sambærilegar við síðari tölur í öllum tilfellum. Skiptir par sérstaklega máli að nokkrir lífeyrissjóðir sem fram til pess tíma höfðu eingöngu starfað sem séreignarsjóðir tóku jafnframt að reka samtryggingardeildir. Var skylduiðgjaldi sem greitt var í pessa sjóði eftir pað skipt milli samtryggingar og séreignar en pað hafði áđur runnið óskipt í séreign. Ákvæði um petta voru í reglugerð nr. 698/1998 sem birt var í desember árið 1998 og byggði á lífeyrisjóðalögunum frá árinu áður.

Með lífeyrissjóðalögunum 1997 var jafnframt lagður grunnur að viðbótarlífeyrissparnaðarkerfi (séreignarsparnaður) sem var ný stoð í lífeyriskerfi landsmanna. Flestir samtryggingarsjóðir hófu í kjölfarið einnig rekstur séreignardeilda. Sjóðir sem áður höfðu eingöngu byggt á séreign hófu jafnframt rekstur samtryggingardeilda.

Fjárfestingarstefna séreignarsjóða getur verið afar ólík milli sjóða og laga- og rekstrar- 
umhverfi slíkra sjóða er um margt annað en sameignarsjóða. Раð gerir samanburð árangurs einstakra sjóða í eignastýringu erfiðan. Í pessari rannsókn verður pví eingöngu horft til samtryggingarsjóða. Peir búa að mestu við sambærilegt laga- og rekstrarumhverfi ef frá er talinn nokkur munur á milli sjóða með og án ábyrgðar launagreiðanda á lífeyrisgreiðslum. Pó verður skoðuð heildarávöxtun 5 lífeyrissjóða sem beina hluta skylduiðgjalds í séreign enda gefur ávöxtun samtryggingardeilda peirra sjóða ekki alltaf rétta mynd af ávöxtun skylduiðgjalds.

Undir lok tíunda áratugarins urðu einnig miklar breytingar á lífeyrissjóðum starfsmanna hins opinbera, m.a. var LSR skipt í tvær deildir, A og B, í ársbyrjun 1997 með lögum nr. 1/1997. Hið fyrra kerfi, fyrir árið 1997, var svokallað hlutfallskerfi par sem lífeyrir er hlutfall af launum. Pví var lokað fyrir nýjum starfsmönnum árið 1997 og peim í pess stað beint í kerfi par sem iðgjöld eru umreiknuð í stig. 2017 var svo kerfinu breytt aftur, ábyrgð launagreiðanda á lífeyrisgreiðslum að mestu afnumin í A deild og réttindaávinnsla jafnframt gerð háð aldri en hún hafði áður verið jöfn alla starfsævina.

Meðal annarra breytinga á tíunda áratugnum má nefna fjárfestingar sjóðanna í erlendum eignum. Heimild til pess fékkst með EES samningnum. Breytingin gerðist í nokkrum skrefum en frá og með árinu 1995 voru erlendar fjárfestingar landsmanna, p.á m. lífeyrissjóða almennt frjálsar, og var svo allt til ársins 2008. Voru erlendar fjárfestingar lífeyrissjóða eftir pað og lagabreytingar 1997 eingöngu takmarkaðar af ákvæðum 36. gr. (nú 36. gr. og gr. 36 a-f) lífeyrissjóðalaganna um fjárfestingar peirra. Par hefur m.a. verið sett pak á gjaldmiðlaáhættu sjóðanna sem nú takmarkar eign í erlendri mynt, án gengisvarna, við $50 \%$ heildareigna. Pá jukust kaup peirra á innlendum hlutabréfum til muna en fyrstu hlutabréfin voru skráð í Kauphöll Íslands (pá Verðbréfaping Íslands) árið 1990 pótt viðskipti hæfust ekki fyrr en síðar.

Árið 1997 voru erlendar eignir sjóðanna enn mjög takmarkaðar pótt peir hafi verið farnir að fjárfesta erlendis af miklum krafti. Á stuttum tíma undir lok tíunda áratugarins og fyrstu ár nýrrar aldar gerbreyttust eignasöfn sjóðanna og áhersla á hlutabréf, bæði innlend og erlend, varð miklu meiri en áður. Fyrstu árin skilaði pessi erlenda fjárfesting almennt góðri ávöxtun og hún, ásamt almennt mjög háum vöxtum á innlendum skuldabréfum, varð til pess að tíundi áratugurinn varð mesta blómaskeið íslenska lífeyriskerfisins, a.m.k. hvað ávöxtun snertir.

Há ávöxtun á hlutabréfamörkuðum var pó sýnd veiði en ekki gefin. Pví kynntust sjóðirnir fyrst um og upp úr aldamótum, m.a. vegna pess að netbólan svokallaða sprakk. Fyrstu ár nýrrar aldar varð ávöxtun sjóðanna fyrir vikið almennt döpur. Рað snerist við og gott betur í eignaverðsbólu áranna 2003-2007 pegar raunávöxtun innlendra hlutabréfa mældist um $50 \%$ á ári.

Sú veisla endaði með hruninu 2008 sem purrkaði nánast út allan innlenda hlutabréfamarkaðinn. Skuldabréfamarkaðurinn fór ekki eins illa út úr hruninu enda stór hluti innlenda markaðarins bréf með ábyrgð ríkisins. Sjóðirnir töpuðu pó töluverðu á skuldabréfum banka og annarra einkaaðila. Jafnframt varð á endanum að afskrifa nokkuð af sjóðfélagalánum, pótt almennt hafi lánasöfn lífeyrissjóðanna reynst mun öruggari en annarra sem einnig höfðu veitt fasteignalán í bólunni.

Hrun krónunnar pýddi að erlendar eignir snarhækkuðu í verði, mælt í krónum. Рað vóg nokkuð á móti verðhruni innlendra eigna lífeyrissjóðanna, pótt peir hafi að nokkru marki verið búnir að verja erlenda eignasafnið fyrir gengissveiflum með samningum við fjármálastofnanir.

Árin eftir hrun hafa einnig verið um margt sérstök fyrir lífeyriskerfið. Lífeyrissjóðir gátu ekki fært fé úr landi, nema í mjög takmörkuðum mæli til að standa við eldri samninga, frá og með haustinu 2008 og allt til ársins 2016. Рað ár voru sjóðunum veittar takmarkaðar heimildir til pess. Heimildirnar voru síðan rýmkaðar hratt og loks fjárfestingarnar gefnar alveg frjálsar í mars árið 2017.

Gjaldeyrishöftin settu sjóðina í prönga stöðu. Ástandið á íslenskum verðbréfamarkaði, 
sem var enn að jafna sig eftir hrunið, hafði sömu áhrif. Lítið framboð var af skráðum innlendum hlutabréfum fyrstu árin eftir hrun, pótt pað færi smám saman vaxandi, og sama mátti segja um skuldabréf fyrirtækja. Pegar fasteignamarkaðurinn tók að hjarna við gátu lífeyrissjóðirnir tekið upp práðinn við fjármögnun hans, ýmist með kaupum á sértryggðum skuldabréfum banka eða með sjóðfélagalánum. Sjóðirnir gátu einnig fjárfest í ýmsum verkefnum sem sneru að endurfjármögnun fyrirtækja sem purftu fjárhagslega endurskipulagningu eftir hrun, m.a. með stofnun Framtakssjóðs Íslands (Ásgeir Jónsson og Alexander Freyr Einarsson, 2018). Skortur á góðum fjárfestingartækifærum pýddi pó að sjóðirnir neyddust um skeið til að eiga verulegar innstæður í bankakerfinu á tiltölulega lágum vöxtum.

Sviptingar urðu ekki eingöngu í eignum og ávöxtun. Ýmsar aðrar breytingar urðu einnig á pessu tímabili. Pannig fækkaði lífeyrissjóðum til muna með fjölda samruna úr 66 sjóðum í árslok 1997 i 24 sjóði í árslok 2017. Fjölmargar breytingar voru jafnframt gerðar á lagaumhverfi sjóðanna, m.a. var fjárfestingarheimildum peirra breytt ítrekað.

\subsection{Skrif annarra}

Áhrif hrunsins árið 2008 á eignasöfn lífeyrissjóðanna eru að nokkru rakin í skýrslu úttektarnefndar frá árinu 2012 (Hrafn Bragason, Héðinn Eyjólfsson og Guðmundur Heiðar Frímannsson, 2012). Sú skýrsla hefur pó pann galla að einblína á verðpróun og ávöxtun á tiltölulega stuttu tímabili Рað gefur ekki góða mynd af árangri við eignastýringu lífeyrissjóða sem er í eðli sínu langtímaverkefni. Meðal annars má hafa í huga að umtalsverður hluti peirra verðmæta sem hurfu, á pappír, árið 2008 hafði í raun orðið til með örri verðhækkun áranna á undan. Pessi grein bætir úr pví með pví að skoða ávöxtun yfir mun lengra tímabil sem gefur eðlilegri mynd af árangri sjóðanna.

I skýrslu FME frá árinu 2014 (FME, 2014) er góð lýsing á íslenska lífeyriskerfinu og forsaga pess rakin. Pá er ítarlega fjallað um samspil hinna ýmsu stoða kerfisins, bæði samtryggingar, séreignar og almannatrygginga. Allnokkur umræða er um áhættu í kerfinu en ekki gerð tilraun til að mæla eða áætla hana.

Í bók Ásgeir Jónssonar og Hersis Sigurgeirssonar frá árinu 2014 er einkum horft til framtíðar og greint hvernig lífeyrissjóðir geta sem best ávaxtað pað fé sem streyma mun inn í sjóðina næstu áratugi. Horfa peir Ásgeir og Hersir par einkum til erlendra fjárfestinga. Sama efni var jafnframt til skoðunar í (Gylfi Magnússon o.fl., 2017).

Fjárfestingar og ávöxtun lífeyrissjóða voru greindar í (Kristíana Baldursdóttir, 2000). Par er einkum horft til kerfisins í heild en einnig birtar ávöxtunartölur fyrir nokkra lífeyrissjóði yfir nokkurra ára tímabil. Gylfi Magnússon (2013) skoðaði jafnframt sögulega ávöxtun kerfisins í heild, tímabilið 1971-2012, en ekki ávöxtun einstakra sjóða.

\section{Aðferðafræði}

\section{1 Útreikningur á ávöxtun}

Ýmsar leiðir eru pekktar við mat á árangri í sjóðstjórnun. Algengt er að reiknuð sé út annars vegar ávöxtun sjóðs og hins vegar viðmiðs (e. benchmark) og niðurstöðurnar svo bornar saman. Önnur algeng leið er að reikna út áhættupóknun sjóða, p.e. ávöxtun umfram áhættulausa vexti, og jafnframt pá áhættu sem tekin var, mæld með t.d. sveiflum í ávöxtun, og leggja svo mat á hvort áhættupóknunin var mikil eða lítil í hlutfalli við pá áhæettu sem tekin var.

Hér verða báðar leiðir farnar. Pó verður einungis takmörkuð umfjöllun um samanburð við ávöxtun viðmiðs. Ástæða pess er fyrst og fremst að ekki eru aðgengilegar tölur um ávöxtun allra peirra eignaflokka sem sjóðirnir fjárfesta í. Sérstaklega vantar vísitölu fyrir ávöxtun skuldabréfa banka eða annarra fyrirtækja en tap á fjárfestingum í peim vóg nokkuð pungt í slæmri ávöxtun sjóðanna árið 2008. Pá er ekki augljóst hvernig taka á tillit til gengisvarna við útreikning á ávöxtun viðmiðs enda fyrirliggjandi upplýsingar um pær 
varnir takmarkaðar. Engu að síður verður reiknað út einfalt viðmið (e. benchmark) fyrir sjóðina sem lýst er hér að neðan enda varpar samanburður við pað nokkru ljósi á árangur eignastýringar sjóðanna.

Pví verður hér fyrst og fremst byggt á tölum um ávöxtun eigna einstakra lífeyrissjóða og reiknaðar út sveiflur í peirri ávöxtun. Niðurstöðurnar eru bæði skoðaðar einar og sér og með samanburði við ávöxtun áhættulausra eigna og fyrrnefnt viðmið. Raunávöxtun áhættulausra eigna verður metin út frá ávöxtunarkröfu til verðtryggðra skuldabréfa með ríkisábyrgð, ýmist spariskírteina eða bréfa Íbúðalánasjóðs eða forvera hans. ${ }^{2}$

Vegna pess hve mikið hefur verið um samruna lífeyrissjóða á pví tímabili sem er til skoðunar eiga margir núverandi sjóðir sér marga forvera. Í grundvallaratriðum er hægt að taka á pví með tvennum hætti. Annars vegar er hægt að reikna ávöxtun núverandi sjóðs út frá ávöxtun allra forveranna. Pað jafngildir pví að reikna ávöxtun eins og samrunarnir hefðu orðið strax í upphafi tímabilsins pótt peir hafi í raun orðið síðar. Hins vegar er hægt að reikna ávöxtun forveranna fram að samruna og skeyta aftan við pá tímaröð ávöxtun arftakanna eftir samruna. Síðari leiðin er að pví leyti betri að hún sýnir hvaða ávöxtun sjóðfélagar í tilteknum sjóðum sem til voru í upphafi nutu í raun pegar upp var staðið. Hér verða báðar leiðirnar skoðaðar, p.e. bæði birt ávöxtun núverandi sjóða að teknu tilliti til allra forvera hvers sjóðs og ávöxtun upphaflegra sjóða (ýmist miðað við 1993, 1997 eða 2000) og arftaka peirra. Óhjákvæmilegt er við greiningu á árangri í eignastýringu lífeyrissjóða að taka fullt tillit til sjóða sem hafa horfið af sjónarsviðinu með samruna við aðra sjóði. Sé pað ekki gert verða niðurstöðurnar skekktar af svokallaðri seiglubjögun (e. survivorship bias). Hún er vel pekkt vandamál við mat á árangri í eignastýringu yfir tíma (Elton, Gruber og Blake, 1996).

Ýmsir samtryggingarsjóðir eru reknir í fleiri en einni deild eða voru reknir með peim hætti um skeið. Frá sjónarhóli launpega skiptir í raun ekki máli pótt hans lífeyrissjóður starfræki aðrar deildir en pá sem hann greiðir í pví hann öðlast ekki nein réttindi í peim (nema hann greiði einnig í pær). Pví má líta á lífeyrissjóð með tvær deildir sem tvo lífeyrissjóði, jafnvel pótt stjórn og skrifstofuhald sé sameiginlegt. Pegar eðlismunur er á sjóðunum, eins og á LSR A annars vegar og LSR B hins vegar, er vart annað hægt en að líta á pað sem tvo sjóði. Pví var sú leið farin að greina ávöxtun LSR eins og tvo sjóði væri að ræða. Рað sama var gert vegna Brúar af sömu ástæðu og sá sjóður greindur sem prjár deildir (A, B og V) par sem hægt var að koma pví við með góðu móti. Nokkrir sjóðir sem skiptust í fleiri en eina deild um stutt skeið en sameinuðu pær svo fyrir lok pess tímabils sem hér er til skoðunar eru hins vegar greindir sem einn sjóður og ávöxtun á hverjum tíma reiknuð sem vegið meðaltal allra samtryggingardeilda viðkomandi sjóðs.

Við byrjum á pví að skoða ávöxtunina eina og sér, án tillits til áhættu og án samanburðar við viðmið eða áhættulausar eignir. Fyrst parf pó að skoða hvernig hægt er að taka tillit til verðbólgu og til hreinna iðgjalda. Tölurnar sem byggt er á og koma frá FME eru

2 Hér er um vexti til langs tíma að ræða. Langtímaskuldabréf eru almennt ekki áhættulaus fjárfesting til skamms tíma vegna pess að ávöxtunarkrafa peirra og par með markaðsverð getur sveiflast töluvert. Ef kaupandi á bréfin til gjalddaga ætti hann hins vegar að fá pegar upp er staðið pá ávöxtun sem upphaflegt kaupverð peirra endurspeglaði. Ef ætlunin væri að finna áhættulausa skammtímavexti væri eðlilegra að miða við skammtímaverðbréf, t.d. ríkisvíxla. Almennt er pó eðlilegra fyrir lífeyrissjóði að fjárfesta í langtímaskuldabréfum en skammtíma, m.a. vegna pess að ávöxtun peirra löngu er almennt hærri. Pví er ávöxtun ríkisvíxla eða sambærilegra bréfa ekki eðlilegt viðmið fyrir sjóðina. Hér verður til einföldunar litið á ávöxtunarkröfu verðtryggðra langtímabréfa með ríkisábyrgð í upphafi hvers árs sem áhættulausa vexti pað ár. Í pessu samhengi má benda á að pegar lífeyrissjóðir færa skuldabréf ekki til eignar á markaðsvirði heldur uppreiknaðri kaupkröfu pá horfa peir framhjá sveiflum í markaðsverði vegna sveiflna í ávöxtunarkröfu á markaði með sama hætti og hér er gert. Vegna pess að áhættulausir vextir hafa almennt farið lækkandi á peim tíma sem hér er til skoðunar mælast meðaláhættulausir vextir aðeins lægri en raunveruleg ávöxtun sem fengist hefði með kaupum á langtímaskuldabréfum vegna pess að markaðsverð bréfanna hefði hækkað með lækkun kröfunnar. M.ö.o. kaupendur hefðu getað bókfært háa ávöxtun snemma á líftíma bréfanna en lága ávöxtun seint á líftíma bréfanna. Petta pýðir að sögulegir áhættulausir vextir svona reiknaðir eru aðeins skekktir niður á við meðan vextir fara lækkandi. 
árstölur, annars vegar um hreina eign í upphafi og lok árs og hins vegar um iðgjöld og lífeyrisgreiðslur hvers árs. Allar tölurnar eru á verðlagi hvers tíma.

Til að reikna ávöxtun parf í grundvallaratriðum að reikna breytingu á hreinni eign milli ára og draga frá hrein iðgjöld á árinu. Jafnframt parf að taka tillit til pess að hrein iðgjöld hvers árs ávaxtast hluta pess árs. Féð sem verið er að ávaxta er pví hrein eign í upphafi árs, sem er ávöxtuð allt árið, og hrein iðgjöld, sem eru ávöxtuð hluta ársins. Par eð engar upplýsingar liggja fyrir um pað í gögnunum hvernig hrein iðgjöld skiptast á einstaka hluta ársins verður hér gert ráð fyrir að pau hafi að meðaltali verið greidd inn á miðju ári og á meðalverðlagi ársins. ${ }^{3}$ Meðalverðlag ársins er reiknað sem einfalt meðaltal af vísitölu neysluverð í lok árs og í lok ársins á undan. Jafna 1 sýnir útreikning á raunávöxtun tiltekins árs, $t$.

$$
r_{t}=\frac{W_{t}-W_{t-1} \cdot \frac{P_{t}}{P_{t-1}}-I_{t} \frac{P_{t}}{\left(P_{t}+P_{t-1}\right) / 2}}{W_{t-1} \cdot \frac{P_{t}}{P_{t-1}}+\frac{I_{t}}{2} \cdot \frac{P_{t}}{\left(P_{t}+P_{t-1}\right) / 2}}
$$

Par sem $t$ táknar tíma, $r$ ávöxtun, $W$ hreina eign, $I$ iðgjöld og $P$ verðlag. Vegna pess að reiknuð ávöxtun byggir hér á aukningu á hreinni eign pá er allur kostnaður sjálfkrafa dreginn frá, bæði kostnaður vegna eignastýringar og annar rekstrarkostnaður sjóðanna og jafnframt öllum tekjum bætt við, bæði iðgjöldum og öðrum (sem eru yfirleitt óverulegar). Í teljara jöfnu (1) er pví ávöxtun í krónum á árslokaverðlagi og í nefnara áætluð meðalstærð viðkomandi sjóðs á sama ári, einnig á árslokaverðlagi.

Gögn FME eru Excel skjöl sem byggja á skýrslum sem sjóðirnir hafa skilað til stofnunarinnar og er talnaefni að mestu samhljóða ársreikningum. Einnig voru allmargir ársreikningar lífeyrissjóða skoðaðir vegna rannsóknarinnar, m.a. vegna pess að par er að finna skýringar sem ekki eru birtar í skýrslum FME. Miðað er við hreina eign eins og hún er reiknuð út af FME. Pví er almennt ekki tekið á ýmsum álitamálum varðandi mat á eignum, m.a. hvaða ávöxtunarkröfu eigi að gera við mat á skuldabréfum. Nokkuð mismunandi er að hve miklu leyti lífeyrissjóðir meta skuldabréfaeign sína á markaðsvirði og að hve miklu leyti peir meta hana á uppreiknuðu kaupverði miðað við ávöxtunarkröfu pegar bréfin voru keypt. Sumir sjóðir meta öll skuldabréf á markaðsverði (eða áætluðu markaðsverði) en aðrir einungis hluta skuldabréfa sinna. ${ }^{4}$ Reglur FME veita svigrúm að pessu leyti. ${ }^{5}$

Pegar ávöxtunarkrafa skuldabréfa á markaði fer almennt lækkandi, eins og gerst hefur allan pann tíma sem hér er til skoðunar, pýðir petta að skuldabréf sem metin eru miðað við kaupkröfu eru metin töluvert undir markaðsvirði peirra. ${ }^{6}$ Sjóðir sem meta ekki öll

3 Ýmsir lífeyrissjóðir reikna ávöxtun m.v. mun styttri tímabil en eitt ár, t.d. mánuð eða jafnvel dag. Pegar pað er gert getur fengist aðeins önnur niðurstaða fyrir meðalávöxtun ársins en pegar árstölur eru notaðar. Munurinn ætti pó almennt að vera lítill og ekki kerfisbundinn (p.e. ýmist verða ávöxtunartölur byggðar á tíðari mælingum hærri eða lægri en pær sem byggja á árstölum). Pó er hugsanlegt að ungur sjóður sem vex mjög hratt og er pví með meiri hluta iðgjalda á síðari hluta ársins mælist með of lága ávöxtun vegna pessa, p.e. nefnarinn í jöfnu (1) sé pá of hár og verðlagsleiðrétting iðgjalda í teljara leiði til ofmats á peim.

4 Sjóðirnir meta hins vegar almennt sjóðfélagalán miðað við stöðu lánanna á hverjum tíma, e.t.v. með varúðarniðurfærslu vegna affalla.

5 Sbr. gr. 26-28 í reglum nr. 335/2015 um ársreikninga lífeyrissjóða. Í fyrri reglum, nr. 55/2000, var í 28. gr. miðað við að skuldabréf væru færð til eignar miðað við ávöxtunarkröfu pegar pau voru keypt, nema pað „[h]afi orðið breyting á markaðsvöxtum, sem telst varanleg og er talin hafa mikil áhrif“.

6 Áhættulausir raunvextir voru um 5,6\% í ársbyrjun 1997 en rétt tæp 2\% í árslok 2017. Раð pýðir að peir hafa lækkað um 0,17 prósentustig að ári að jafnaði. Lækkunin var pó vitaskuld ekki jöfn og samfelld. Skýringarnar á lækkun raunvaxta eru án efa margar en aukinn sparnaður lífeyriskerfisins vegur par pungt enda skýrir kerfið mjög stóran hluta innlends sparnaðar. Árið 2014 voru lífeyrisréttindi einsstaklinga að jafnaði $41 \%$ sparnaðar peirra og fasteignir voru álíka stór hluti eða $42 \%$. Frjáls peningalegur sparnaður, innstæður og verðbréf, var einungis 11\% (Vísbending, 2016). 
skuldabréf á markaðsvirði gefa pó í langflestum tilfellum einnig upp markaðsvirði peirra í skýringum við ársreikninga. Töluverðu munar fyrir lífeyrissjóðakerfið í heild. Pannig var hrein eign til greiðslu lífeyris fyrir samtryggingarsjóði í heild gefin upp 103 milljörðum lægri en ella fyrir vikið í árslok 2017. Munurinn dreifðist á 16 lífeyrissjóði en aðrir færðu allar eignir á ætluðu markaðsverði.

Til að taka tillit til pessa og gera ávöxtunartölur samanburðarhæfar á milli lífeyrissjóða var farin sú leið að reikna hreina eign til greiðslu lífeyris í árslok 2017 miðað við að öll skuldabréf væru metin á markaðsvirði. Рað hækkar allnokkuð sögulega meðalávöxtun sumra sjóðanna pegar innri vextir eru reiknaðir. Hins vegar reyndist ekki með góðu móti hægt að beita sambærilegri leiðréttingu á hreina eign í upphafi tímabilsins. Hún kann pví að vera aðeins ofmetin og par með einnig meðalávöxtun allt tímabilið.7

Ávöxtun skv. jöfnu (1) er ekki alveg sambærileg við pá sem FME reiknar sjálft pótt almennt muni litlu. FME reiknar fyrst út nafnávöxtun og leiðréttir hana fyrir verðbólgu á árinu í heild. Pví er leiðrétting vegna verðbólgu ekki alveg sambærileg við pá sem hér er stuðst við. Раð hefur pó sáralítil áhrif. Meiru skiptir að FME reiknaði um skeið nafnávöxtun án nokkurra liða, p.e. pví sem flokkast sem „aðrar tekjur og önnur gjöld“ og „óreglulegir liðir og matsbreytingar" ${ }^{8}$ Í flestum tilfellum eru pessir pættir raunar núll eða óverulegir og pá gefur aðferð FME nánast alveg sömu niðurstöðu og jafna (1). Í nokkrum tilfellum eru peir hins vegar allháir og verður pá talsverður munur á raunávöxtun skv. FME og peirri sem fæst með jöfnu (1). FME reiknaði lengst af nafnávöxtun út frá jöfnu (2) og síðan raunávöxtun út frá jöfnu (3) fyrir sjóði sem ekki reiknuðu daglegt gengi sjálfir.

$$
\begin{gathered}
i_{t}=\frac{F_{t}-K_{t}}{\left[W_{t}+W_{t-1}-\left(F_{t}-K_{t}\right)\right] / 2} \\
r_{t}=\frac{1+i}{\frac{P_{t}}{P_{t-1}}}-1
\end{gathered}
$$

Par sem $i$ eru nafnvextir, $W_{t-1}$ er hrein eign í upphafi árs, $W_{t}$ er hrein eign í lok árs, $F$ eru hreinar fjárfestingartekjur og $K$ hreinn rekstrarkostnaður. Bæði $F$ og $K$ eru án óreglulegra liða og matsbreytinga. Fyrir sjóði sem reikna daglegt gengi hefur FME notast við gengisskráningu í upphafi og lok árs til að reikna nafnávöxtun ársins í stað jöfnu (2) og síðan leiðrétt fyrir verðbólgu með jöfnu (3).

Líta má svo á að jöfnur (2) og (3) saman reikni raunávöxtun af reglulegri starfsemi lífeyrissjóðs á tilteknu ári en jafna (1) raunávöxtun að teknu tillit til allra tekna og gjalda og matsbreytinga. Fyrir sjóðfélaga skiptir niðurstaðan úr jöfnu (1) væntanlega meira máli pví að hún sýnir aukningu á hreinni eign til greiðslu lífeyris umfram hrein iðgjöld. Pegar

7 Áhrifin eru pó lítil vegna pess að eignir lífeyrissjóðanna voru miklu minni í upphafi en í lok tímabilsins, jafnvel að teknu tilliti til verðbólgu. Smáskekkja í eignamati í upphafi hefur pví miklu minni áhrif á mælda meðalávöxtun en sambærileg skekkja, hlutfallslega, undir lok tímabilsins. Hrein eign samtryggingarsjóða var 337 milljarðar í árslok 1997 en 3.550 milljarðar í árslok 2017. Рað samsvarar meira en ferföldun að raunvirði.

8 Útreikningarnir byggðu lengst af á reglum nr. 55/2000 um ársreikninga lífeyrissjóða. Í peim var ávöxtun reiknuð án liða 9 (óreglulegar tekjur og gjöld) og 10 (matsbreytingar) í fyrsta hluta viðauka reglnanna. Reikniaðferðinni var síðan breytt með reglum nr. 335/2015 og eftir pað voru pessir liðir teknir með í útreikningi á ávöxtun. Fyrir gildistöku reglna 55/2000 reiknaði FME ávöxtun án tillits til annars rekstrarkostnaðar en pess sem talinn var tengjast fjárfestingum. Útreikningar FME á ávöxtun hafa pví breyst í grundvallaratriðum prisvar á pví tímabili sem hér er til skoðunar. Pað gerir tölur frá mismunandi tíma ekki fyllilega sambærilegar pótt breytingarnar hafi ekki verið stórvægilegar. Auk pess hefur FME notað aðeins aðra aðferð til að reikna út ávöxtun sjóða sem reikna daglegt gengi en annarra. 
matsbreytingar hafa áhrif á reiknaða ávöxtun á tilteknu ári getur ávöxtun pess árs pó mælst skrýtin skv. jöfnu (1). Рað ætti hins vegar að jafnast út pegar meðalávöxtun yfir lengra tímabil er reiknuð.

I nokkrum tilfellum má sjá að FME hefur reiknað út ávöxtun út frá jöfnum (2) og (3) en síðan er önnur ávöxtunartala, sem slegin hefur verið beint inn í Excel skjölin án pess að sýna útreikninga, birt í töflum. Er ávöxtunartalan sem er birt yfirleitt hærri en sú sem fékkst út frá jöfnum (2) og (3). Pá birtir FME í nokkrum tilfellum ekki ávöxtunartölur fyrir alla lífeyrissjóði eða birtir ekki ávöxtun fyrir tilteknar samtryggingardeildir sérstaklega. Í nokkrum tilfellum er ávöxtun gefin upp sem $0 \%$ pótt pað virðist vart geta staðist.

Í langflestum tilfellum eru tölur FME um iðgjöld og hreina eign pannig að lítill vandi er að reikna ávöxtun út frá jöfnu (1). Pó komu upp allmörg álitamál við reikninginn. Árið 1997 og fyrstu árin par á eftir eru nokkrar flækjur í gögnunum vegna stofnunar séreignadeilda hjá sjóðum sem áður voru eingöngu með samtryggingardeildir eða stofnunar samtryggingadeilda hjá sjóðum sem áður voru eingöngu með séreignarsparnað. Yfirleitt tókst pó að greiða úr peim flækjum.

Pá má sjá að hrein eign til greiðslu lífeyris í lok tiltekins árs í tölum fyrir pað ár er ekki alltaf sama talan og gefin er upp í tölum fyrir árið á eftir en í yfirliti fyrir hvert ár má sjá slíkar tölur fyrir tiltekið ár og árið á undan. Stundum gerist petta í tengslum við samruna sjóða, p.e. hrein eign sameinaðs sjóðs í upphafi er ekki alveg sama talan og síðasta uppgefin hrein eign sjóðanna sem sameinuðust. Líklegasta skýringin er að petta hafi gerst vegna endurmats á eignum en einnig er hugsanlegt að gjöld eða tekjur hafi verið færð á tiltekið ár eftir að gengið var frá ársreikningi pess árs. Reynt var eins og hægt var að greiða úr slíkum flækjum en stundum var álitamál hvernig pað ætti að gera. Oftast var um lágar upphæðir að ræða, pótt pær hefðu pó markverð áhrif á mælda ávöxtun tiltekinna sjóða. Stundum var pó munurinn verulegur og snerti marga sjóði. Pannig má sérstaklega nefna að í yfirliti um eignir samtryggingarsjóða fyrir árið 2015 er heildar hrein eign til greiðslu lífeyris í lok pess árs metin um 30 milljörðum lægri en í yfirlitinu sem birt var ári síðar. Munurinn samsvarar rétt um 1\% af heildareignum sjóðanna.

\section{2 Útreikningur á meðalávöxtun}

Pegar meðalávöxtun er reiknuð parf fyrst að svara lykilspurningunni hvers konar meðaltal á að styðjast við? Í grundvallaratriðum koma prjár leiðir til greina. Sú fyrsta er að reikna hefðbundið (e. arithmetic) meðaltal, sem er einfaldlega fengið með pví að finna hlutfallslega ávöxtun hvers árs, leggja saman tölurnar fyrir öll árin og deila með fjölda ára. Jafna 4 sýnir hvernig reiknað er.

$$
\bar{r}=\frac{\sum_{t=1997}^{2017} r_{t}}{21}
$$

Pótt hefðbundið sögulegt meðaltal hafi nokkra kosti, m.a. er hægt að rökstyðja að pað sé besta leiðin til að spá framtíðarávöxtun m.v. pá forsendu að sagan endurtaki sig, pá er algengara að styðjast við margfeldismeðaltal (e. geometric) pegar söguleg ávöxtun í eignastýringu er reiknuð. Eins og áður er pá byrjað með hlutfallslega ávöxtun hvers árs. Síðan er hún umreiknuð yfir í margfeldisáhrif og pau svo margfölduð saman fyrir öll árin. Loks er uppsöfnuðum margfeldisáhrifum vegna ávöxtunar fyrir allt tímabilið skipt jafnt á öll árin. Jafna 5 sýnir petta.

$$
\bar{r}=\sqrt[21]{\prod_{t=1997}^{2017}\left(1+r_{t}\right)}-1
$$


Báðar fyrrnefndar aðferðir við að reikna út meðaltal hafa pann galla að pær taka ekki tillit til pess hve mikið fé var ávaxtað hverju sinni. Par með er horft fram hjá pví að fyrir sjóðfélaga skiptir töluverðu máli hvort góð ávöxtun náðist pegar sjóðirnir voru stórir eða pegar peir voru litlir. Vegna pess að sjóðirnir fara enn langflestir vaxandi par eð iðgjöld eru hærri en lífeyrisgreiðslur (og auk pess vaxa peir vegna ávöxtunar) pá gefa fyrrnefndar aðferðir pví ávöxtun í upphafi tímabilsins of mikið vægi en ávöxtun í lok tímabilsins á móti of lítið vægi.

Hægt er að taka á pessum vanda með pví að reikna virðisvegið meðaltal (e. value weighted). Рað er fengið með pví að reikna út innri vexti (e. internal rate of return) ${ }^{9}$ fyrir tímaröð par sem fyrsta gildið er hrein eign sjóðs í upphafi (p.e. í ársbyrjun 1997 í flestum tilfellum), síðan koma í réttri röð (m.V. mitt ár) hrein iðgjöld á ári frá 1997 til 2017 og lokagildið er síðan staðan í árslok 2017. Öll gildin í tímaröðinni nema pað síðasta fá neikvætt formerki við útreikning innri vaxta pví að pau jafngilda innborgunum í viðkomandi sjóð. Allar tölurnar purfa að vera á sama verðlagi, p.e. umreiknaðar til t.d. verðlags í lok tímabilsins með vísitölu neysluverðs, til að fá út raunvexti. Innri vextir eru lausn fyrir $r$ í jöfnu (6). Reiknaðir voru út innri vextir miðað við tvær aðferðir, annaðhvort bókfærða hreina eign til greiðslu lífeyris í árslok 2017 eða hreina eign að teknu tilliti til vanmats á markaðsvirði skuldabréfaeignar hjá 16 sjóðum eins og áður var vikið að.

$$
W_{1996} \cdot \frac{P_{2017}}{P_{1996}}=-\sum_{t=1997}^{2017} I_{t} \cdot \frac{P_{2017}}{P_{t}} \cdot \frac{1}{(1+r)^{t-1996,5}}+\frac{W_{2017}}{(1+r)^{2017-1996}}
$$

\section{3 Áhrif ríkisins og samtryggingar á ávöxtun}

Rétt er að vekja athygli á pví að með ávöxtun er hér átt við ávöxtun lífeyrissjóðanna sjálfra. Ávöxtun iðgjalda er alla jafna hins vegar mjög mismunandi frá sjónarhóli einstakra iðgjaldagreiðenda. Рað liggur í eðli samtryggingar. Sumir fá aldrei neitt greitt úr sínum sjóði, p.e. ef peir látast áður kemur að töku lífeyris og skilja ekki eftir sig maka eða börn sem fá greiðslur. Aðrir piggja lífeyri mjög lengi. Reiknuð ávöxtun iðgjalda peirra verður pá mun hærri en annarra að meðaltali.

Pá er rétt að hafa í huga að ávöxtun iðgjalda allra iðgjaldagreiðenda sem heildar í tiltekinn sjóð er í raun lægri en ávöxtun sjóðsins sjálfs vegna tekjutenginga í almannatryggingakerfinu. M.ö.o., ráðstöfunartekjur peirra vaxa ekki jafnmikið og ávöxtun lífeyrissjóðs peirra gefur til kynna. Раð er fyrir utan efni pessarar greinar að reikna ávöxtun að teknu tilliti til pess en pó verður málið stuttlega reifað hér að neðan.

Í árslok 2017 mátti rekja 40,6\% hreinnar eignar samtryggingarsjóða til hreinna iðgjalda áranna 1997-2017, 20,9\% til eignar sjóðanna í ársbyrjun 1997, 24,2\% til ávöxtunar peirra eigna sem sjóðirnir áttu í ársbyrjun 1997 og 14,2\% til ávöxtunar hreinna iðgjalda áranna 1997-2017. Ef við horfum framhjá pví að hluti hreinnar eignar sjóðanna í ársbyrjun 1997 (p.e. hluti fyrrgreindra 20,9\%) var vegna ávöxtunar sem náðist fyrir árið 1997 pá má pví líta svo á að $24,2 \%+14,2 \%$ eða 38,4\% hreinnar eignar nú sé vegna ávöxtunar. Afgangurinn er vegna iðgjalda sl. 21 ár eða eignar í ársbyrjun 1997.

Petta pýðir að ef bætur almannatrygginga lækka um meira en 38,4 krónur fyrir hverjar 100 sem meðallífeyrispegi fær úr lífeyrissjóði vegna tekjutengingar ellilífeyris pá myndi öll raunávöxtun lífeyrissjóðanna sl. 21 ár í renna óbeint í ríkissjóð. Skerðingarhlutfallið er í raun aðeins hærra en petta á árinu 2018, p.e. $45 \%$ af tekjum fyrir ofan frítekjumark,

9 Einnig er hægt að reikna meðaltal sem kalla má virðisvegið með einfaldari aðferð. Pá er reiknað vegið meðaltal raunávöxtunartalna yfir pað tímabil sem er til skoðunar par sem hver ávöxtunartala hefur vægi sem er í hlutfalli við pað fé sem ávaxtað var pað ár. Almennt ætti niðurstaðan að verða svipuð og fæst með jöfnu (6) pótt alltaf muni einhverju. 
sem er 25.000. ${ }^{10}$ Skerðingin hættir pegar lífeyristekjur ná 557.187 á mánuði. Peir sem hafa tekjur yfir peim mörkum fá ekki greiddan ellilífeyri frá almannatryggingum. Fyrir pá sem fá á bilinu 25.000 til 557.187 á mánuði úr meðallífeyrissjóði er pví hægt að líta svo á að öll raunávöxtun sl. 21 ár og rétt ríflega pað renni óbeint í ríkissjóð. Raunávöxtun skyldulífeyrissparnaðar frá sjónarhóli slíks sjóðfélaga er pví neikvæð.

Tekjutenging bóta almannatrygginga hefur að auki veruleg áhrif til jöfnunar tekna lífeyrispega. Vegna hennar skiptir talsvert minna máli en ella fyrir lífeyrispega hvort hann á réttindi í lífeyrissjóði sem hefur náð góðri ávöxtun. Sömleiðis skiptir minna máli en ella hvernig lýðfræðileg samsetning sjóðfélaga í viðkomandi sjóði er, sbr. umfjöllun í kafla 4.3.

Að auki skiptir skattlagning máli. Sú frestun á álagningu tekjuskatts og útsvars sem er innbyggð í lífeyriskerfið skiptir pó furðulitlu máli nema skatthlutföll breytist mikið yfir tíma, p.e. séu önnur pegar skattfrestunin hefst, við greiðslu iðgjalda, en pegar henni lýkur, p.e. pegar lífeyrir er greiddur. Petta gildir a.m.k. fyrir pá sem hafa pað háar tekjur að pær eru yfir skattfrelsismörkum bæði meðan peir eru á vinnumarkaði og pegar peir piggja lífeyri.

Meiru skiptir að lífeyrissjóðir eru undanpegnir greiðslu fjármagnstekjuskatts. Raunávöxtun peirra væri mun lægri ef peir nytu ekki peirrar undanpágu. Ef sjóðirnir hefðu t.d. greitt fjármagnstekjuskatt af allri nafnávöxtun sinni á hverju ári frá árinu 1997 m.v. skatthlutföll á hverjum tíma pá hefði meðalraunávöxtun peirra (m.v. margfeldismeðaltal og bókfært mat eigna) lækkað á árunum 1997-2017 úr 3,73\% í 2,66\%. Рað hefði samsvarað $28,8 \%$ skattlagningu á raunvexti. ${ }^{11}$

\section{3 Ávöxtun einstakra tímabila}

Ávöxtun sjóðanna verður hér reiknuð með nokkrum mismunandi aðferðum, eins og áður var rakið, og fyrir nokkur mismunandi tímabil. Lok allra tímabilanna verður pó pað sama, p.e. árslok 2017, en upphafið ýmist 1993, 1997, 2000 eða 2009. Ástæðurnar fyrir pví að fjögur mislöng tímabil eru skoðuð eru:

a) Tölur allt aftur til 1993 eru eingöngu til fyrir hluta sjóðanna. Eingöngu er hægt að reikna út margfeldismeðaltal fyrir árin 1993-1997 og er pá byggt á mati FME.

b) Tölur fyrir flesta sjóðina eru til allt aftur til 1997 og er pví mest áhersla lögð á pað tímabil.

c) Nokkrir sjóðir, sem höfðu upphaflega verið séreignarsjóðir, hófu ekki rekstur samtryggingardeilda fyrr en eftir 1997. Tölur fyrir samtryggingardeildir peirra eru pó til a.m.k. frá árinu 2000.

d) Stuttlega er greint frá ávöxtun frá og með 2009 til að skoða árangur eftir hrun.

Pá verður einnig sérstaklega skoðuð ávöxtun sjálft hrunárið, p.e. 2008.

10 Fyrir pá sem fá heimilisuppbót hækkar skerðingarhlutfallið um 11,9 prósentustig en hér er horft framhjá pví. Jafnframt er ekki tekið tillit til annarra tekna en greiðslna úr lífeyrissjóði og almannatryggingum.

11 Stofn fjármagnstekjuskatts er reiknaður miðað við nafnávöxtun, ekki raunávöxtun. Pess vegna er skatthlutfallið mjög breytilegt í raun eftir pví annars vegar hver raunávöxtun er hverju sinni og hins vegar hver verðbólgan er. Skatthlutfallið er í raun alltaf hærra en uppgefin tala nema verðlag standi í stað eða hjaðni. 


\subsection{3-2017}

Mynd 1 sýnir meðalraunávöxtun peirra tólf sjóða sem upplýsingar liggja fyrir um allt aftur til 1993. Miðað er við tölur FME um 5 ára meðalávöxtun fyrir árin 1993-1997, p.e. byggt á jöfnum (2) og (3) en eftir pað er byggt á jöfnu (1). Ávöxtunartölurnar eru almennt hærri en fyrir tímabilið 1997-2017, p.e. ávöxtun áranna 1993-1996 var hærri en að jafnaði síðar. Í öllum tilfellum nema einu er meðalávöxtun á ári yfir ávöxtunarviðmiði lífeyrissjóða, raunar oftast vel yfir pví. Nokkrir pessara sjóða mátu hluta skuldabréfa sinna undir markaðsvirði í árslok 2017 og myndi pví ávöxtun tímabilsins mælast aðeins hærri ef tekið væri tillit til pess.

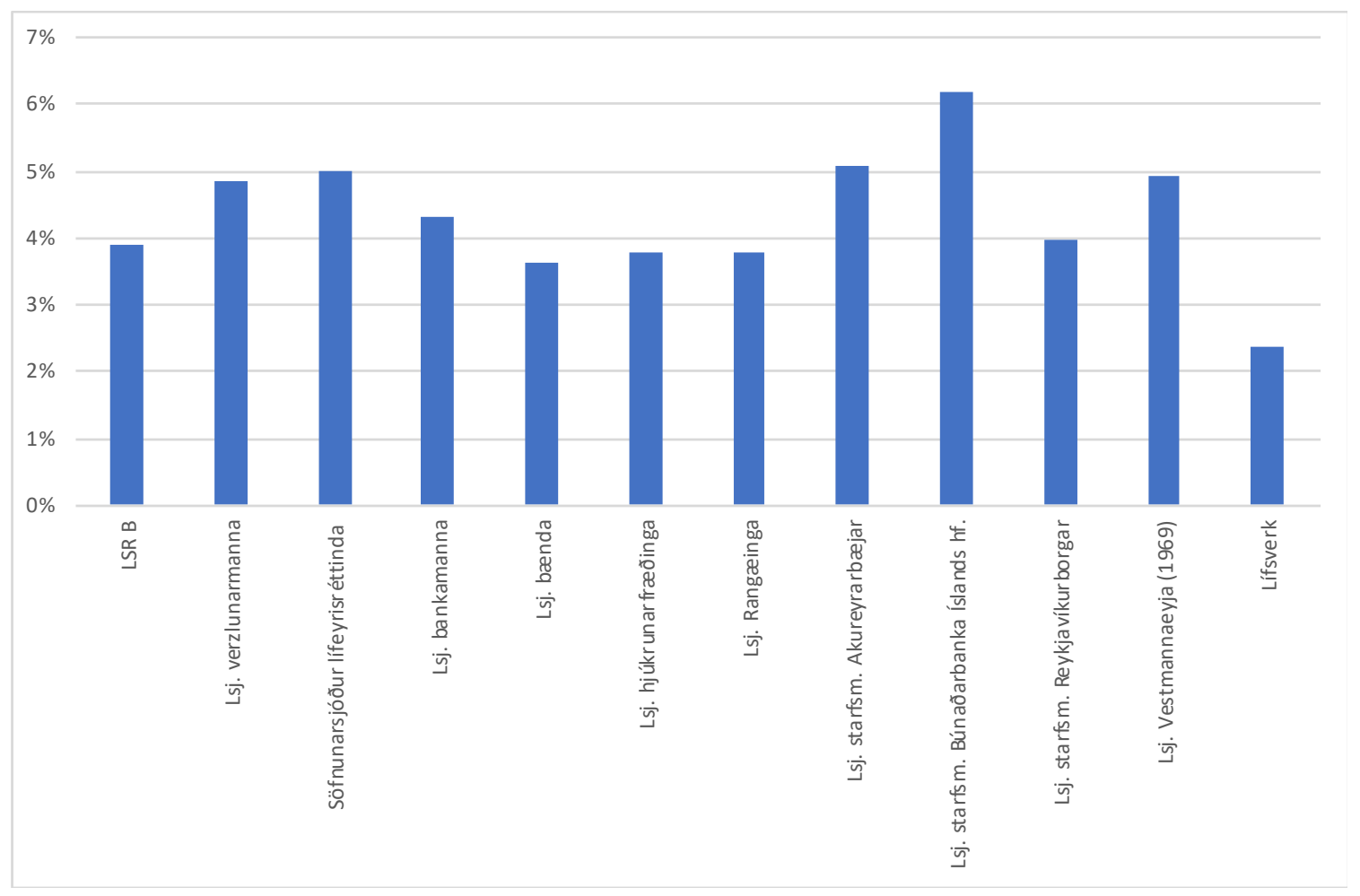

Mynd 1. Meðalávöxtun tólf sjóða 1993-2017

Margfeldismeðaltal miðað við bókfært verð eigna. 


\subsection{7-2017}

Mynd 2 sýnir meðalraunávöxtun (margfeldismeðaltal) 49 lífeyrissjóða sem voru starfandi árið 1997 að meðaltali yfir allt tímabilið 1997 til 2017. Tölurnar fyrir pá sjóði sem sameinuðust öðrum á tímabilinu miða við ávöxtun sameinaða sjóðsins eftir sameiningu. Miðað er við bókfært verð eigna. Petta er sú ávöxtun sem náðst hefur frá sjónarhóli peirra sem voru félagar í viðkomandi lífeyrissjóðum í upphafi tímabilsins.

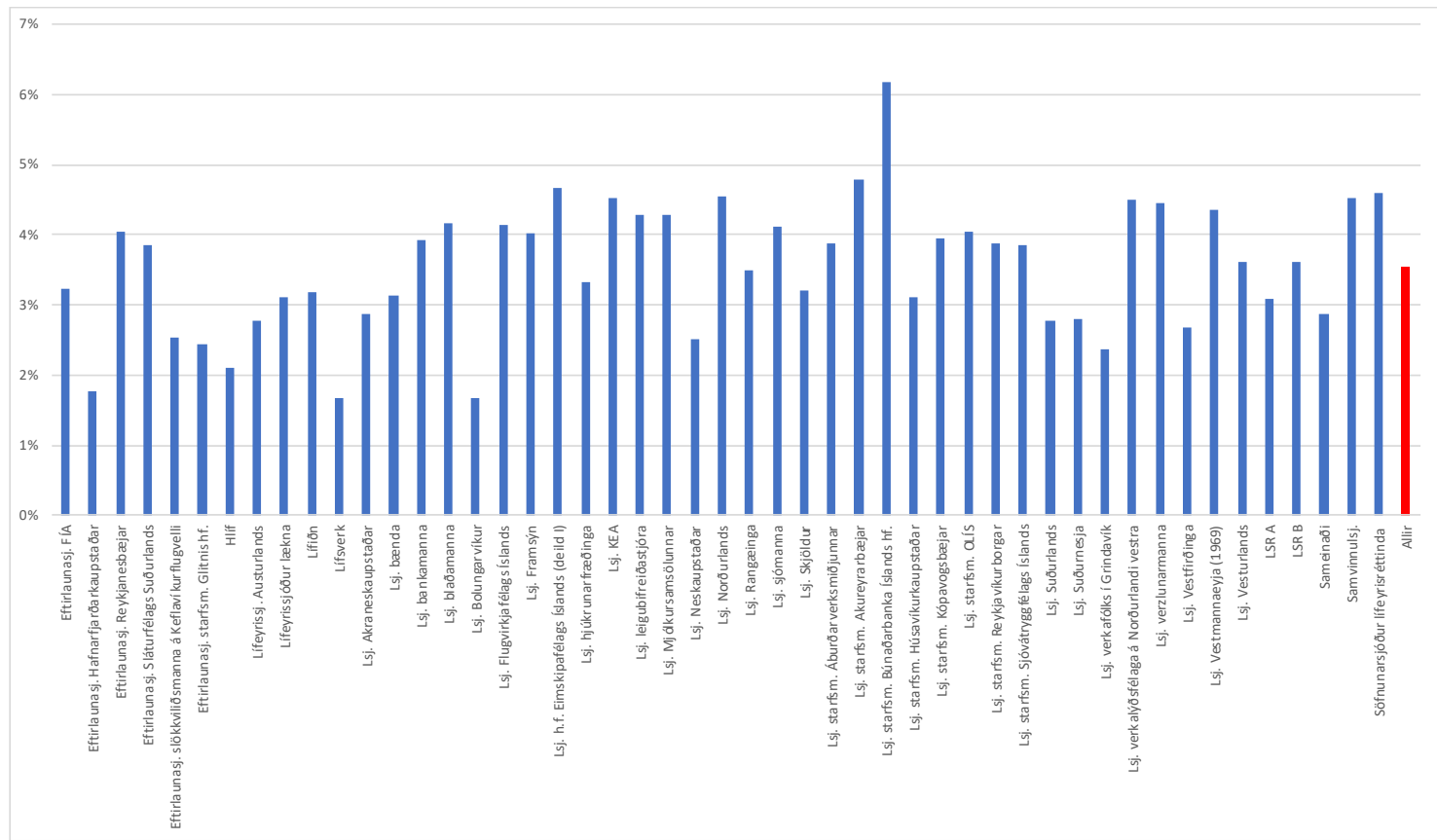

Mynd 2. Meðalraunávöxtun 49 upphaflegra sjóða og arftaka peirra 1997-2017

Margfeldismeðaltal miðað við bókfært verð eigna.

Meðalávöxtun (vegið með stærð) allra sjóða á myndinni er 3,7\% en óvegið meðaltal 3,5\%. Skýringin á pví að síðari talan er lægri en sú fyrri er að almennt skiluðu stærri sjóðir aðeins hærri ávöxtun en smáir. ${ }^{12}$ Mjög miklu munar á einstaka sjóðum. Peir sem skiluðu lægstri ávöxtun náðu 1,7\% en sá sem náði hæstri ávöxtun 6,2\%. Meðalávöxtunin petta tímabil er pó ekki fjarri ávöxtunarviðmiði sjóðanna, sem er 3,5\%. Рað er út af fyrir sig áhugaverð niðurstaða í ljósi pess að á miðju tímabilinu hrundi íslenska fjármálakerfið og pví fylgdi gríðarleg eyðilegging peningalegra eigna.

E.t.v. má túlka pessa niðurstöðu pannig að íslenska lífeyriskerfið hafi staðið hrunið af sér. Рað á pó ekki við um alla sjóði pví að ávöxtunin var sem fyrr segir mjög misjöfn. Рað dregur fram áhættuna sem felst í pví fyrir tiltekinn einstakling að eiga lífskjör sín á efri árum undir einum tilteknum sjóði. Pannig náðu prír sjóðir ávöxtun sem var helmingi lægri en ávöxtunarviðmið sjóðanna og einungis rétt rúmur helmingur (26 af 49) náði viðmiðinu á pessu tímabili.

Ávöxtun undir 3,5\% viðmiðinu til langs tíma pýðir að líklegt er að sjóðir purfi að færa niður réttindi sjóðfélaga, p.e. lækka greiðslur til núverandi lífeyrispega og hægja á réttindaávinnslu peirra sem enn greiða iðgjöld. Pó skiptir einnig máli hvernig lýðfræðilegar breytur, sérstaklega lífslíkur og örorkutíðni, próast. Fyrir liggur að margir lífeyrissjóðir gátu fært upp réttindi fyrir 2008 vegna góðrar ávöxtunar en purftu að færa pau niður eftir 2008. Pað getur haft umtalsverð áhrif á lífskjör núverandi og tilvonandi lífeyrispega. Pann-

12 Petta er pekkt mynstur úr eignastýringu og má meðal annars rekja til pess að hlutfallslegur rekstrarkostnaður stærri sjóða er lægri en smærri og að stærri sjóðirnir njóta hagkvæmni stórrekstrar (e. economies of scale) í rannsóknum á fjármálamörkuðum og fjárfestingartækifærum. Sjá t.d. töflu 12.1 í (Piketty, 2013). 
ig hefur kerfið nokkur einkenni happdrættis par sem sumir eru „heppnir“ með sjóð og fá góð réttindi, aðrir „óheppnir“. Í pví samhengi skiptir pó ekki einungis ávöxtun eigna máli heldur einnig lýðfræðilegar breytur eins og nánar verður vikið að síðar.

Ofangreint átti pó ekki við um sjóði með ábyrgð launagreiðanda par sem launpegum voru tryggð ákveðin réttindi (e. defined benefit) óháð ávöxtun sjóðanna. Í peim sjóðum báru launagreiðendur (fyrst og fremst ríkið og sveitarfélög) áhættu af ávöxtun og próun lýðfræðilegra breyta en ekki sjóðfélagar.

Vegna pessa parf að hafa fyrirvara við samanburð á annars vegar sjóðum með ábyrgð launagreiðenda og hins vegar öðrum samtryggingarsjóðum pví að sveiflur í ávöxtun höfðu mjög ólík áhrif milli kerfa á pví tímabili sem er til skoðunar. Pess má geta að meðalávöxtun sjóða með ábyrgð launagreiðanda $(3,8 \%)$ var nánast sú sama og hjá sjóðum án ábyrgðar launagreiðanda (3,7\%). Âvöxtun fyrrnefndu sjóðanna var pó aðeins stöðugari en hinna sem gefur veika vísbendingu að peir hafi tekið minni áhættu. ${ }^{13}$ Staðalfrávik ávöxtunar sjóða með ábyrgð var 7,0\% en sjóða án ábyrgðar 7,8\%.

Félagar í lífeyrissjóði greiða yfirleitt inn í sjóð yfir langt tímabil, p.e. alla starfsævina, og pví ávaxtast fé peirra í mislangan tíma. Iðgöld sem greidd eru pegar starfsmaður er ungur ávaxtast í miklu lengri tíma en pau sem greidd eru undir lok starfsævinnar. Í ljósi pess getur verið gagnlegt að skoða ávöxtun frá aðeins öðru sjónarhorni en bara meðalávöxtun yfir langt tímabil og skoða pess í stað ávöxtun iðgjalda sem greidd eru jafnt og pétt yfir sama tímabil. Mynd 3 sýnir petta. Par er gert ráð fyrir að sama upphæð, 100 krónur á föstu verðlagi, sé greidd inn í upphafi hvers árs frá 1997-2017 og síðan skoðað hve mikil eign ætti að vera fyrir hendi í árslok 2017 miðað við að sú ávöxtun hafi náðst sem tiltekinn lífeyrissjóður (og arftakar hans) náði á hverju ári frá 1997. Byggt er á sömu sjóðum og ávöxtunartölum og í mynd 2.

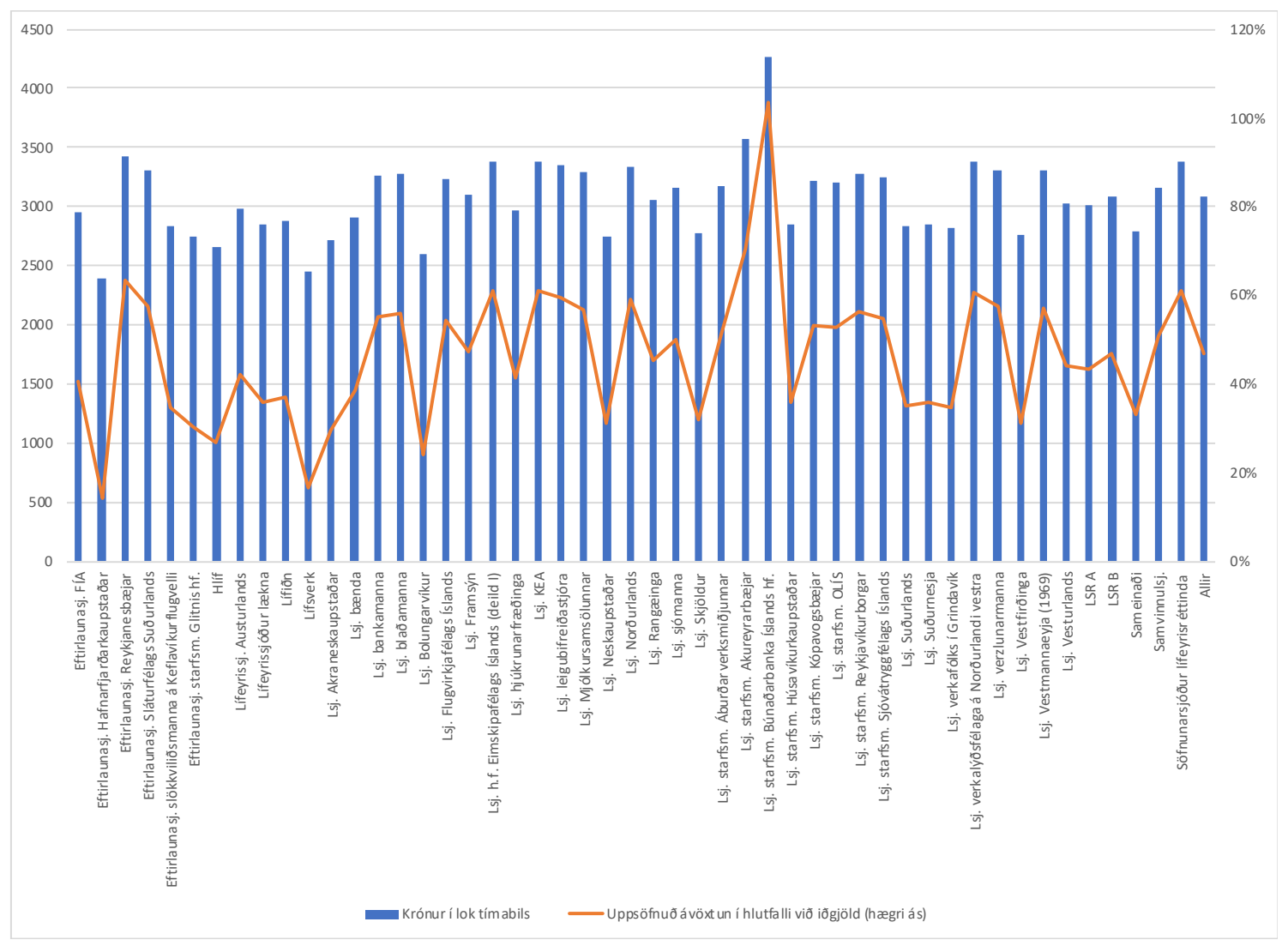

Mynd 3. Afrakstur jafnra iðgjalda, 100 króna á ári, tímabilið 1997-2017

13 Skýringin á pví gæti að einhverju leyti legið í mismunandi fjárfestingarheimildum peirra fyrstu árin, p.e. sjóðir með ábyrgð launagreiðanda bjuggu við meiri takmarkanir. 
Eins og sjá má pá munar töluverðu en pó minnu en á mynd 2. Skýringin er að lífeyrispegar fá ekki eingöngu ávöxtunina greidda heldur einnig iðgjöldin sjálf. Рað dregur aðeins úr mun milli lífeyrissjóða. Hann er pó töluverður. Að meðaltali skiluðu pessar inngreiðslur eign upp á 3.083 krónur í lok tímabilsins, p.e. 2.100 krónum í iðgjöld og 983 krónum í ávöxtun. Ávöxtunin bætti pví 46,8\% við iðgjöldin samanlagt, p.e. hver króna í iðgjöldum stendur undir 1,47 krónum í lífeyri. Hjá peim sjóði par sem ávöxtunin skilaði minnstu var hún hins vegar einungis rétt tæpar 300 krónur. Meðalsjóðfélagi í peim sjóði ættu pví að fá að jafnaði einungis 2.399/3.083 eða 77,8\% af pví sem félagi í meðalsjóði fær fyrir iðgjöldin sín og fá 1,14 krónur fyrir hverja eina sem greidd er í iðgjöld. ${ }^{14}$ Sá sjóður sem skilaði mestu náði hins vegar að rétt ríflega tvöfalda iðgjöldin, p.e. meðalsjóðfélagi gat átt von á 2,03 krónum í lífeyri fyrir hverja eina í iðgjöld.

Mynd 4 birtir enn aðra sýn á ávöxtunina. Í stað pess að rekja sögu upphaflegra sjóða til loka tímabilsins eru peir sjóðir sem voru starfræktir í lok tímabilsins ${ }^{15}$ skoðaðir með forverum sínum. M.ö.o. eru sameiningarnar nú raktar í öfuga átt miðað við mynd 2.

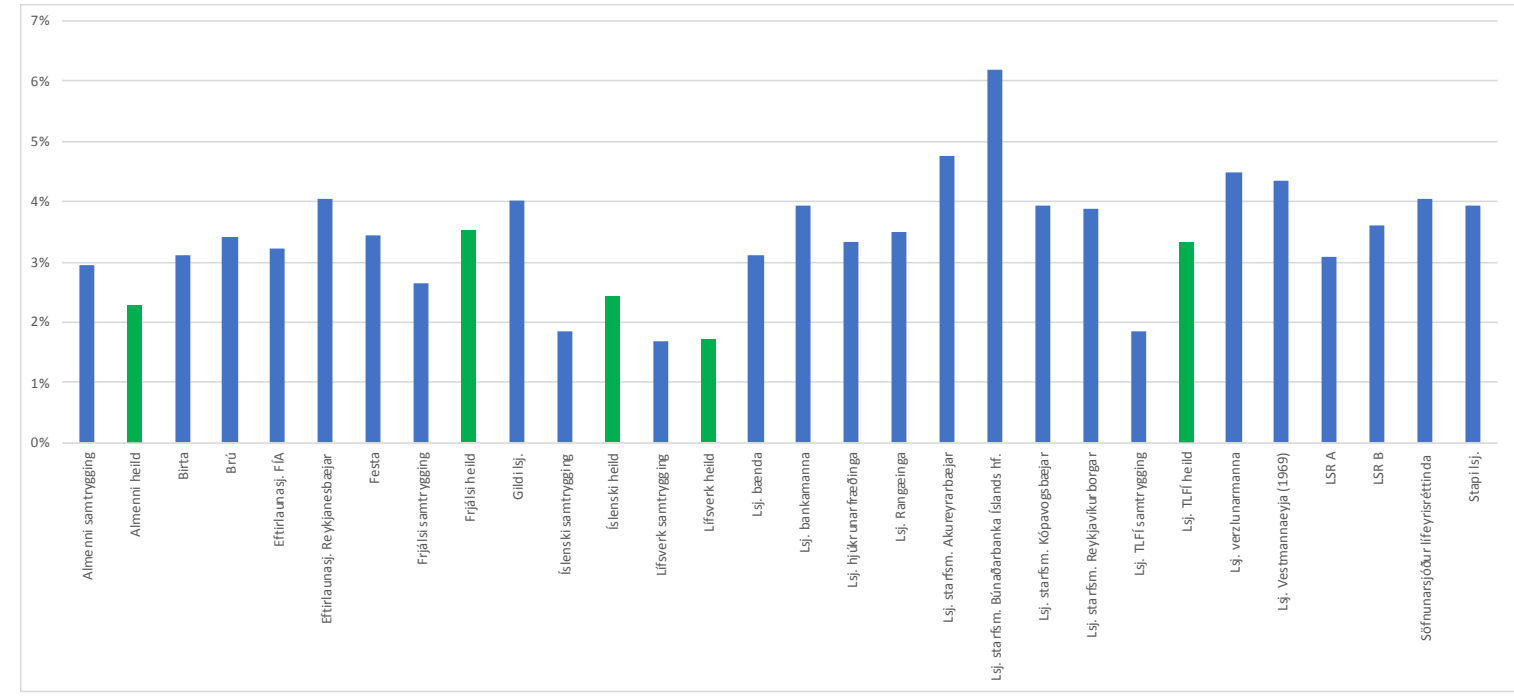

Mynd 4. Meðalraunávöxtun 1997-2017 sjóða sem störfuðu í árslok 2017 og forvera peirra

Margfeldismeðaltal. Fyrir 5 sjóði sem beina hluta skylduiðgjalds í séreign er jafnframt birt heildarávöxtun viðkomandi sjóða, p.e. bæði séreignar og samtryggingar (grænar súlur). Fyrir grænu súlurnar er ekki reiknað með áhrifum samruna. Fyrir tvo peirra sjóða (Íslenski og Lsj. TLFÍ) miðast bláu súlurnar við árin 2000-2017. Byggt er á bókfærðu verði eigna

Ástæða pess að birtar eru tvær súlur fyrir 5 sjóði á mynd 4 er að viðkomandi sjóðir beina sem fyrr segir hluta skylduiðgjalds í séreignarsjóði. Ávöxtun samtryggingardeilda pessara sjóða segir pví ekki alla söguna um ávöxtun skylduiðgjalda. Pví er bæði birt ávöxtun samtryggingar og heildarávöxtun viðkomandi sjóða, p.e. bæði samtryggingardeilda og séreignardeilda. Rétt er að hafa í huga að séreignardeildir pessara sjóða ávaxta pó ekki eingöngu fé sem er hluti skylduiðgjalds heldur einnig fé sem greitt hefur verið í sjóðina vegna viðbótarlífeyrisparnaðar. Ekki er pó auðvelt að greina par á milli enda eru hlutföllin mili annars vegar viðbótarlífeyrissparnaðar og hins vegar séreignarsparnaðar vegna skylduiðgjalds breytileg yfir tíma og mismunandi milli sjóðfélaga. Auk pess er ávöxtun mismunandi milli einstakra deilda í séreign.

14 Hér er til einföldunar horft framhjá hugsanlegri ábyrgð launagreiðanda á iðgjöldum og gert ráð fyrir að lýðfræðilegar breytur séu eins milli sjóða. Pá er tímabilið sem hér er til skoðunar vitaskuld styttra en meðalstarfsævi og horft er framhjá hugsanlegri ávöxtun eftir að sjóðfélagi fer að piggja lífeyri.

15 Eftirlaunasjóður Reykjanesbæjar sameinaðist B deild Brúar á árinu 2017. Hann er engu að síður hafður með hér. Eru ávöxtunartölur fyrir hann árið 2017 reiknaðar út frá ávöxtun B deildar Brúar. 
Mynd 5 er sambærileg við mynd 4 nema að á peirri síðari er meðalávöxtun reiknuð út frá innri vöxtum og eingöngu er miðað við samtryggingardeildir. ${ }^{16}$ Sýndir eru innri vextir miðað við annars vegar bókfært verð eigna og hins vegar markaðsverð í lok árs 2017 (sem fyrr segir er ekki leiðrétt fyrir hugsanlegum mun á bókfærðu verði og markaðsverði í upphafi tímabilsins en áhrif pess eru væntanlega tiltölulega lítil).

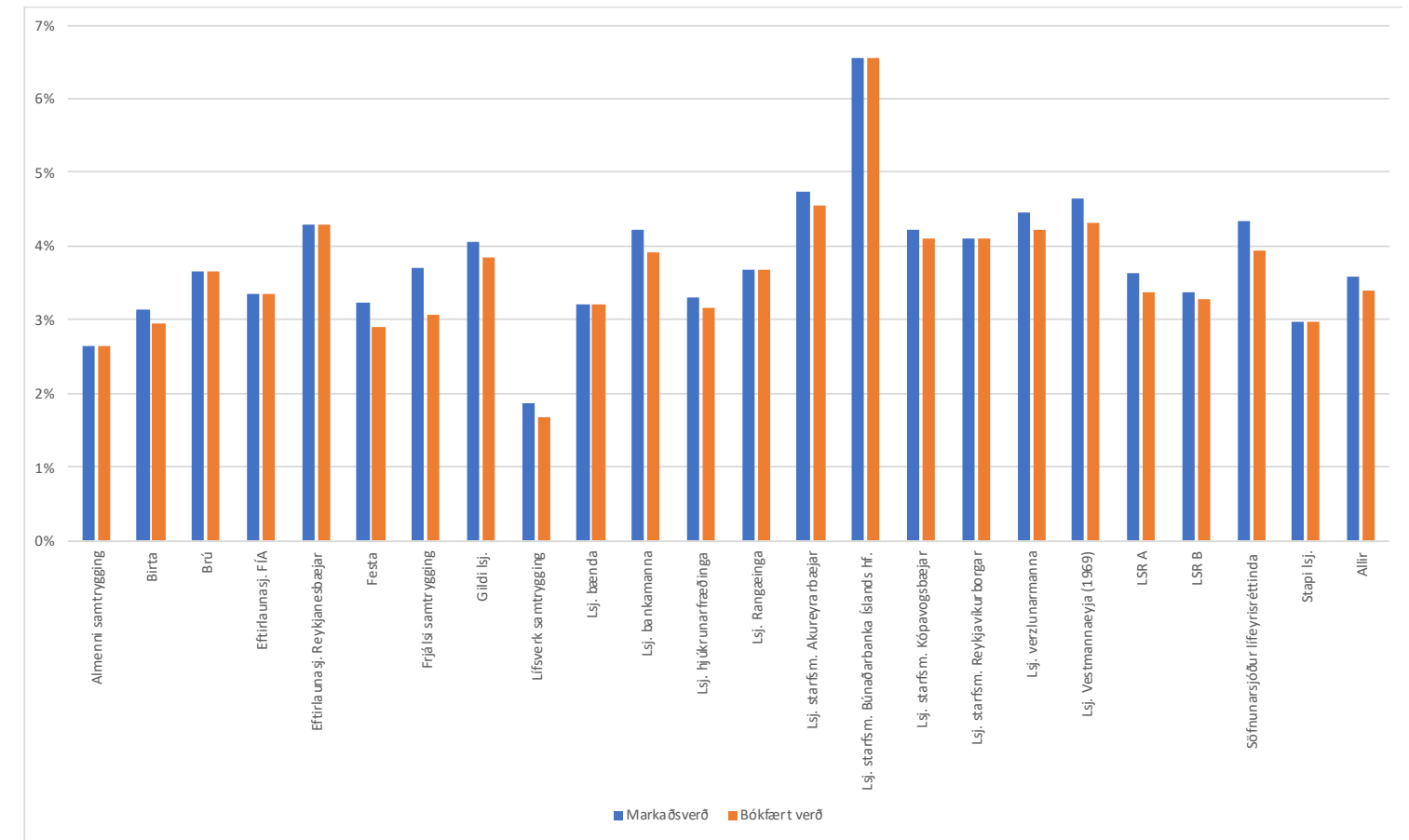

Mynd 5. Raunávöxtun (innri vextir) núverandi sjóða og forvera peirra 1997-2017

Fyrir sjóðina í heild skiptir litlu hvort reiknaðir eru innri vextir eða margfeldismeðaltal, niðurstaðan er svipuð. Innri vextir (3,40\%) eru pó aðeins lægri en margfeldismeðaltalið (3,73\%) pegar miðað er við bókfært virði eigna. Рað endurspeglar væntanlega fyrst og fremst að ávöxtun sjóðanna var lakari pegar peir voru orðnir mjög stórir, p.e. á seinni hluta tímabilsins, sérstaklega árið 2008, en fyrstu ár tímabilsins, pegar sjóðirnir ávöxtuðu minna fé. Fyrir einstaka sjóði er pó stundum talsverður munur á meðalávöxtun eftir pví hvor aðferðin er notuð.

Fyrir pá sjóði sem ekki færðu öll skuldabréf til eignar á markaðsvirði getur verið talsverður munur á meðalávöxtun eftir pví hvort miðað er við bókfært verð eða markaðsverð eigna. Meðalávöxtun allra sjóðanna hækkaði um 0,19 prósentustig, úr 3,40\% 1́ 3,59\%, pegar miðað var við markaðsvirði í stað bókfærðs virðis. Fyrir einstaka sjóði sem færðu hluta skuldabréfa á uppreiknuðu kaupverði var munurinn meiri, að jafnaði 0,24 prósentustig.

16 Tveimur núverandi sjóðum er sleppt vegna pess að hvorki peir né forverar peirra ráku samtryggingardeildir í upphafi tímabilsins. 


\section{$3.32000-2017$}

Mynd 6 er sambærileg við mynd 1 nema að aðeins styttra tímabil er skoðað. Vegna pess bætast við tölur um ávöxtun fimm sjóða sem ekki störfuðu sem samtryggingarsjóðir 1997. Meðalávöxtun er almennt aðeins lægri en á mynd 1 enda var hún há árin 1997-1999.

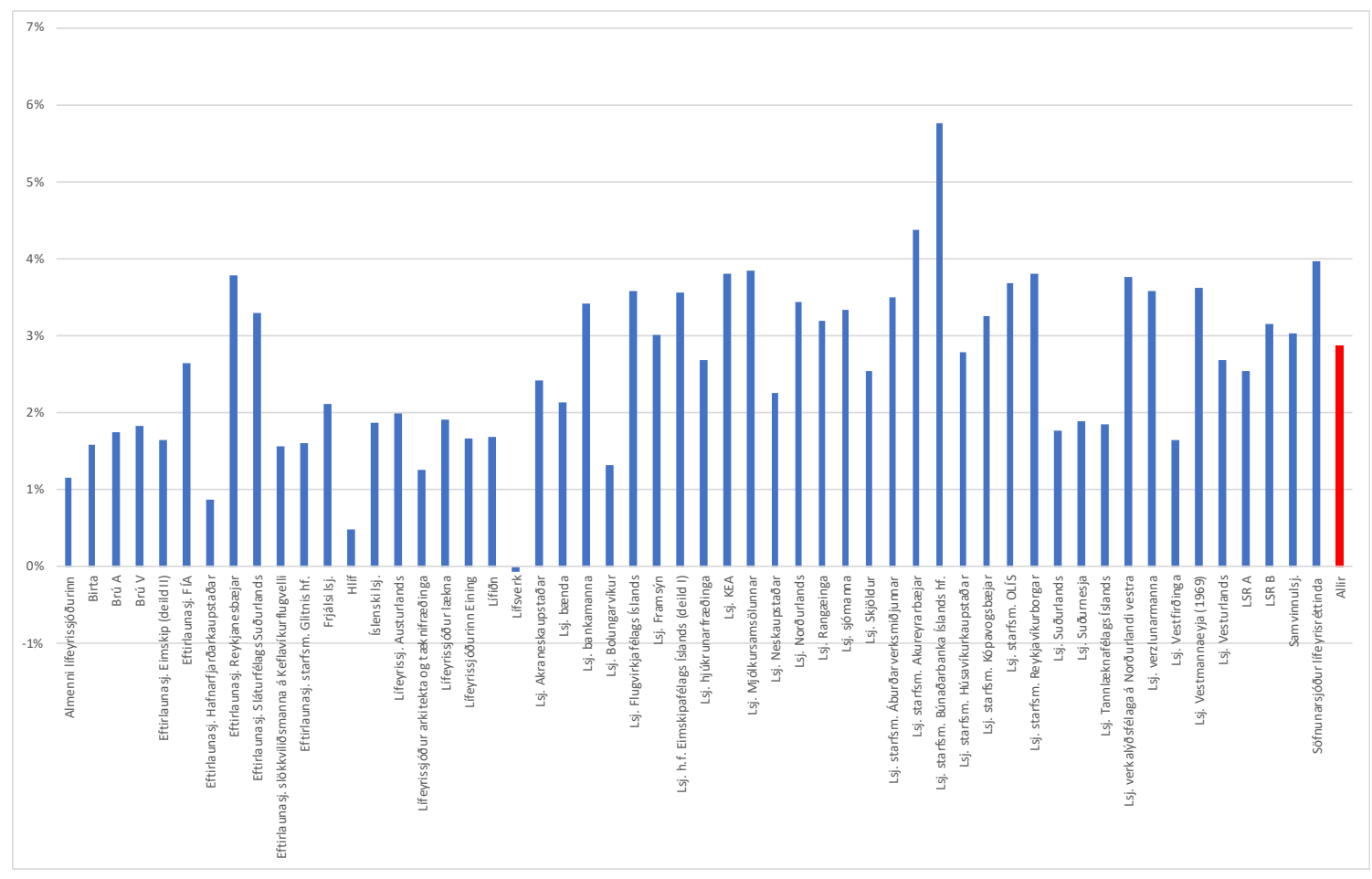

Mynd 6. Meðalávöxtun 54 sjóða sem störfuðu árið 2000 og arftaka peirra árin 2000 til 2017 Margfeldismeðaltal miðað við bókfært verð eigna.

\subsection{9-2017}

Mynd 7 sýnir ávöxtun eftir hrun, p.e. tímabilið 2009 til 2017, fyrir núverandi sjóði og forvera peirra. Eins og sjá má hefur hún verið talsvert betri en fyrir tímabilið 1997-2017. Munurinn liggur eins og nærri má geta fyrst og fremst í pví að̃ nú er hrunárinu 2008 sleppt. Líkt og sjá má á myndinni hefur ávöxtun sl. 9 ár almennt verið góð. Рað endurspeglar m.a. uppsveiflu á innlendum eignamörkuðum eftir eyðileggingu hrunsins, sem hefur t.d. komið fram í hækkun á virði skráðra innlendra hlutabréfa og framtaksfjárfestinga. Að einhverju leyti má líta á pað sem leiðréttingu eignaverðs eftir of mikla lækkun við hrunið og ætti pví að skoða í samhengi við lækkunina 2008. Meðalávöxtun allra sjóða var 4,39\% á pessu tímabili og allir sjóðir nema tveir náðu ávöxtun yfir ávöxtunarviðmiði kerfisins. 


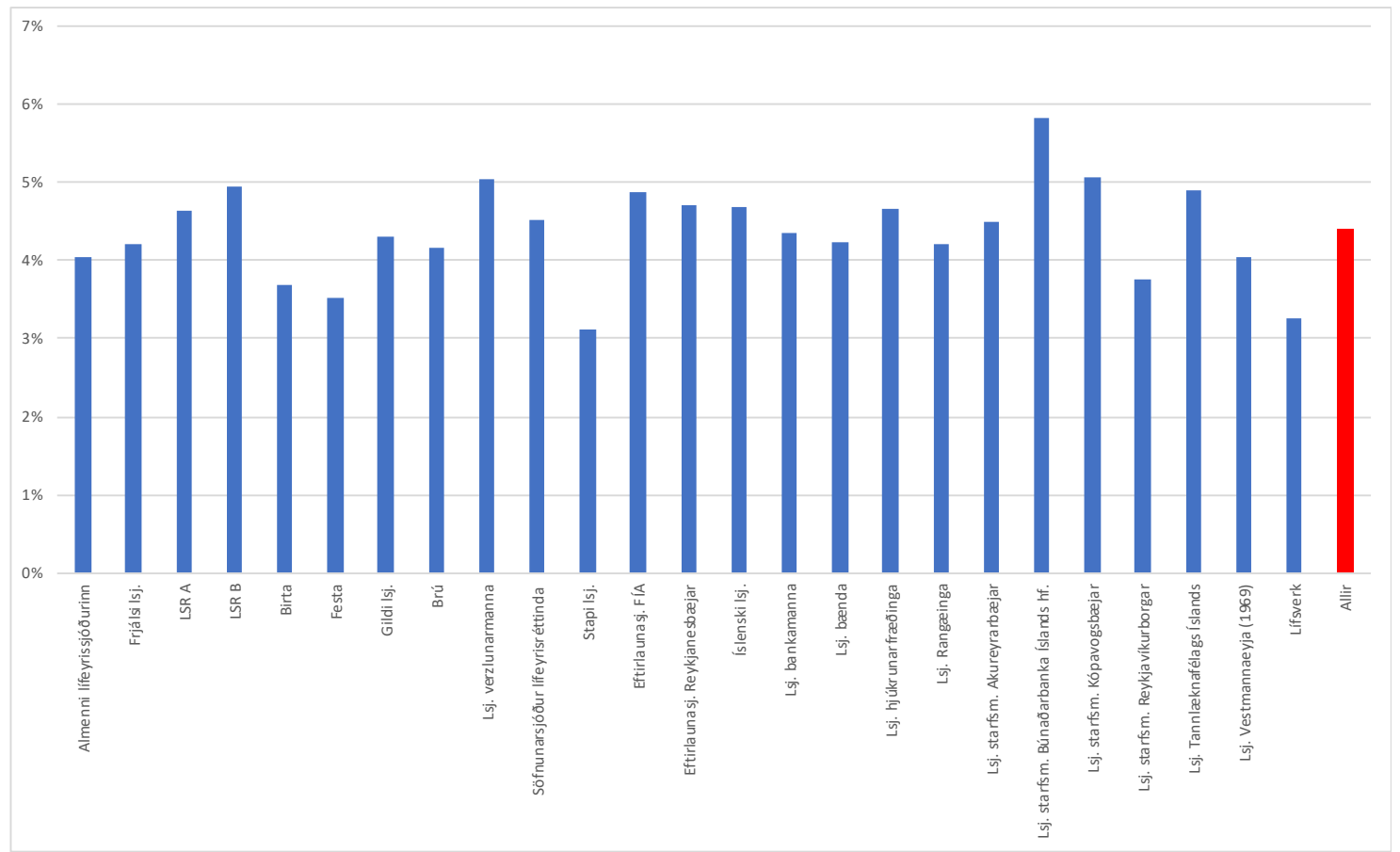

Mynd 7. Meðalávöxtun núverandi sjóða og forvera peirra 2009-2017

Margfeldismeðaltal miðað við bókfært verð eigna.

\subsection{8: Annus horribilis}

Mynd 8 sýnir síðan árið 2008 eitt og sér. ${ }^{17}$ Hrun innlendra eignamarkaða skýrir afleita afkomu pess árs. Innlend hlutabréf urðu í mörgum tilfellum verðlaus og auk pess varð mikið tap á mörgum skuldabréfaflokkum. Erlendar eignir hækkuðu hins vegar í verði, mælt í krónum, pótt pær lækkuðu almennt í erlendri mynt.

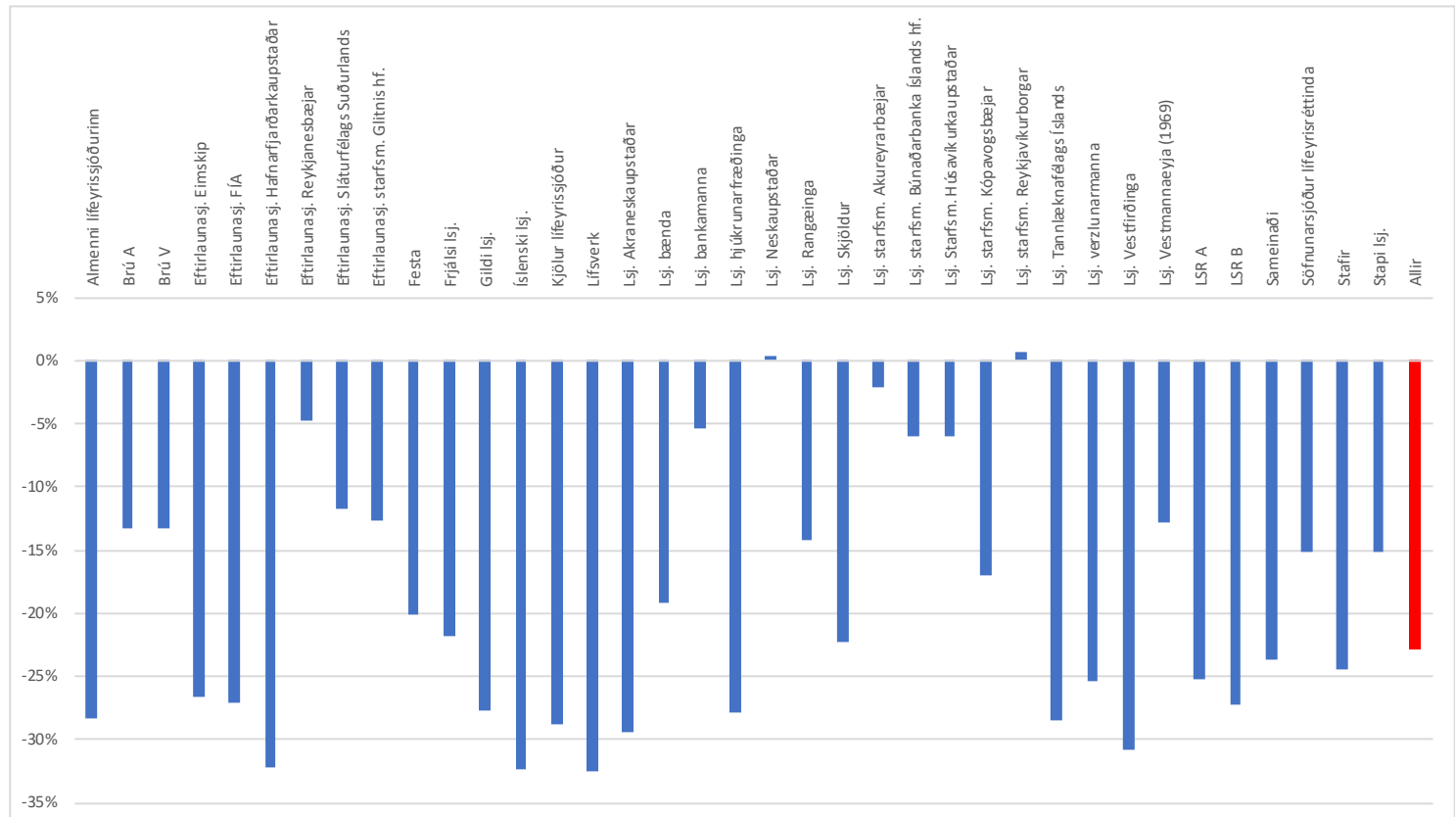

Mynd 8. Raunávöxtun árið 2008. 37 sjóðir sem voru starfandi pað ár

17 Sleppt er tveimur sjóðum sem voru nánast eignalausir og voru pess vegna í raun gegnumstreymissjóðir, p.e. ábyrgðaraðilar sjóðanna greiddu lífeyri sem sjóðfélagar fengu. 
Pótt afkoma kerfisins sem heildar hafi verið afleit árið 2008 og meðalávöxtun allra sjóða verið $-23,0 \%$, pá gekk nokkrum sjóðum miklu betur en öðrum. Skýringin virðist vera að pessir sjóðir höfðu annað hvort aldrei lagt áherslu á pá eignaflokka sem fóru verst út úr hruninu (en höfðu hins vegar skilað góðri ávöxtun á pappír árin á undan) eða drógu mjög úr áherslu á pá eignaflokka í aðdraganda hruns. Í síðari tilfellunum var um tiltölulega litla sjóði að ræða, sem gátu keypt og selt eignir að vild án pess að hafa umtalsverð áhrif á markaðsverð, p.e. sjóðirnir voru verðpegar (e. price takers) á verðbréfamörkuðum og markaðinum fyrir íslensku krónuna, ólíkt stærstu lífeyrissjóðunum.

Pannig kemur fram í ársreikningi Lífeyrissjóðs starfsmanna Reykjavíkurborgar fyrir árið 2008 að erfiðleikar á fjármálamörkuðum höfðu minni áhrif á afkomu sjóðsins en vænta mátti. Par segir jafnframt „Eign í hlutabréfum og hlutabréfasjóðum var lítil og sömuleiðis átti sjóðurinn lítið af skuldabréfum útgefnum af stóru bönkunum. Hins vegar átti sjóðurinn skuldabréf á minni fjármálastofnanir sem og íslensk fyrirtæki sem rétt pótti að færa niður til varúðar [...] Hlutfall pessara eigna var hins vegar mjög lítið af eignasafni sjóðsins og nemur niðurfærslan rúmum 2\% af eignasafninu." (Lífeyrissjóður starfsmanna Reykjavíkurborgar, 2009).

Sömuleiðis kemur fram í ársreikningi Lífeyrissjóðs bankamanna fyrir árið 2007 að vægi hlutabréfa snarminnkaði á pví ári. Sjóðurinn seldi verðbréf með breytilegum tekjum fyrir 17.078 milljónir á pví ári en keypti fyrir 8.205 milljónir. Vægi slíkra bréfa var 45,6\% í árslok 2006 en einungis 11,9\% í árslok 2007 og kemur fram að síðari talan hafi fyrst og fremst verið vegna hlutdeildarskírteina í skuldabréfasjóðum. Hlutabréfaeign, bein eða óbein, hafi verið óveruleg (Lífeyrissjóður bankamanna, 2008).

Lífeyrissjóður starfsmanna Búnaðarbanka seldi hlutabréf í Exista, Landsbanka og Kauppingi á miðju ári 2008. Skuldabréf með ríkisábyrgð voru keypt í staðinn og var verðmæti peirra 11.149 milljónir í árslok en 8.126 milljónir í ársbyrjun (Lífeyrissjóður starfsmanna Búnaðarbanka, 2009).

Viðskipti pessara priggja tiltölulega litlu sjóða í aðdraganda hruns vernduðu pá pví að verulegu leyti fyrir áhrifum hrunsins. Lífeyrissjóðakerfið í heild hefði ekki getað gripið til sömu ráðstafana. Ef einn af stærstu sjóðunum hefði reynt eitthvað svipað hefði pað heldur ekki gengið. Skýringin er stærð kerfisins og stærstu sjóðanna í hlutfalli við íslenskan fjármálamarkað. Pannig hefðu allar tilraunir til að selja íslensk hlutabréf litlu skilað öðru en að flýta fyrir verðlækkun peirra. Tilraunir til að kaupa örugg skuldabréf, t.d. spariskírteini eða húsbréf, hefðu ekki gengið upp af peirri ástæðu að framboð slíkra bréfa var miklu minna en purft hefði til að koma lífeyrissjóðunum sem heild í skjól. Pá hefði ekki gengið að stórauka kaup erlendra eigna vegna áhrifa tilrauna til pess á gengi krónunnar. Petta endurspeglar eina grunnáskorun íslenska lífeyriskerfisins á pessum tíma og enn í dag, p.e. að viðskipti sjóðanna hafa veruleg áhrif á markaðinn og mótaðila skortir ef stór hluti sjóðanna vill gera svipaðar breytingar á eignasöfnum sínum á sama tíma. 


\subsection{7-2017: Kerfið í heild}

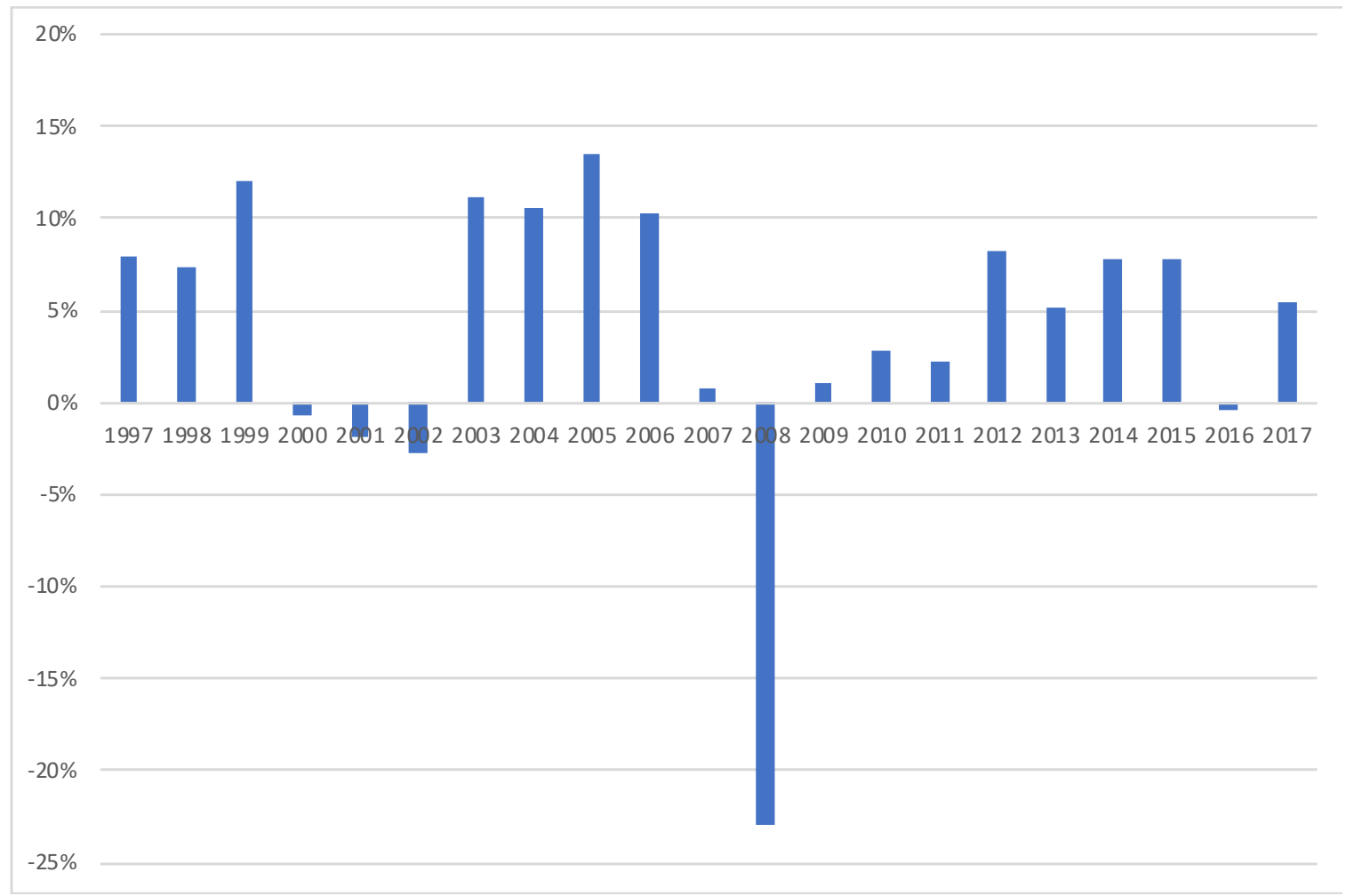

Mynd 9. Ávöxtun samtryggingarsjóða sem heildar 1997-2017

Mynd 9 sýnir raunávöxtun allra samtryggingarsjóða sem heildar eftir árum tímabilið 1997-2017. Í grófum dráttum má skipta tímabilinu í fimm hluta.

1) Mjög góð ávöxtun á tíunda áratugnum (raunar einnig árin á undan 1997) pegar raunvextir skuldabréfa voru mjög háir og hlutabréfaverð hækkaði, bæði hérlendis og erlendis, m.a. vegna netbólunnar svokölluðu. (Meðalávöxtun 9,1\%)

2) Samdráttur 2000-2002 m.a. vegna pess að hlutabréfaverð lækkaði, bæði hérlendis og erlendis. (Meðalávöxtun -1,8\%)

3) Uppgangur í bólunni 2003-2006, m.a. ævintýraleg ávöxtun innlendra hlutabréfa. (Meðalávöxtun 11,3\%)

4) Samdráttur og hrun 2007-2009 pegar innlendur hlutabréfamarkaður nánast purrkaðist út, erlend hlutabréf lækkuðu í erlendri mynt og mikið tap varð á innlendum fyrirtækjaskuldabréfum. (Meðalávöxtun -6,9\%)

5) Vöxtur eftir hrun, 2010-2017, sérstaklega 2012 til 2015 pegar innlendur hlutabréfamarkaður reis aftur upp úr öskustónni og erlend hlutabréf hækkuðu. (Meðalávöxtun $4,5 \%)$

Meðalávöxtun sjóðanna sem heildar er aðeins lægri en áhættulausir vextir fyrir allt tímabilið, pó munar ekki mjög miklu. Pannig voru meðaláhættulausir vextir (m.v. margfeldismeðaltal) fyrir tímabilið 1997-2017 4,01\% en sambærilegt meðaltal fyrir samtryggingarsjóði sem heild var sem fyrr segir 3,73\% ef miðað er við bókfært verð eigna í lok tímabilsins. Væri miðað við markaðsverð mætti væntanlega hækka síðari töluna um u.p.b. 19 punkta sbr. fyrri umfjöllun um innri vexti og pá væri munurinn á ávöxtun kerfisins og áhættulausra vaxta orðinn einungis 9 punktar eða 0,09 prósentustig.

Раð má pví e.t.v. líta svo á að samtryggingarsjóðir sem heild hafi ekki fengið neina áhættupóknun sl. 21 ár en heldur ekki tapað á peirri áhættu sem peir tóku. Pað á pó ekki 
við um einstaka sjóði, sumir peirra náðu umtalsvert betri ávöxtun en fengist hefði með áhættulausri ávöxtun, aðrir mun lakari. Pá er einnig rétt að hafa í huga að lífeyriskerfið í heild hefði aldrei getað ávaxtað allt fé sitt án áhættu vegna pess hve takmarkað framboð var af öruggum eignum.

\section{Greining og mat á árangri}

\section{1 Ávöxtun og áhætta}

Pótt ávöxtunartölur einar og sér gefi vitaskuld nokkra vísbendingu um árangur við eignastýringu er eðlilegt að skoða einnig fleiri pætti. Sérstaklega er algengt að við mat á pví hve góður árangur hefur náðst við eignastýringu sé einnig tekið tillit til áhættu. Hér strax vandast málið pví að margir mælikvarðar á áhættu koma til greina. Hér verður sá algengasti notaður en pað er staðalfrávik ávöxtunar. Pað er pó engan veginn sá eini sem til greina kemur og hægt að finna á peim mælikvarða bæði kosti og galla en peir verða ekki raktir hér.

Mynd 10 sýnir staðalfrávik árlegrar ávöxtunar tímabilið 1997-2017 fyrir 49 samtryggingarsjóði sem voru starfandi árið 1997 og arftaka peirra. ${ }^{18}$ Athyglisvert er hve mikill munur er á staðalfrávikinu og par með peirri áhættu sem sjóðirnir hafa tekið - eða a.m.k. peim sveiflum sem hafa orðið á ávöxtun peirra. Petta sýnir að verulegur munur hefur verið á eignastýringu milli sjóða.

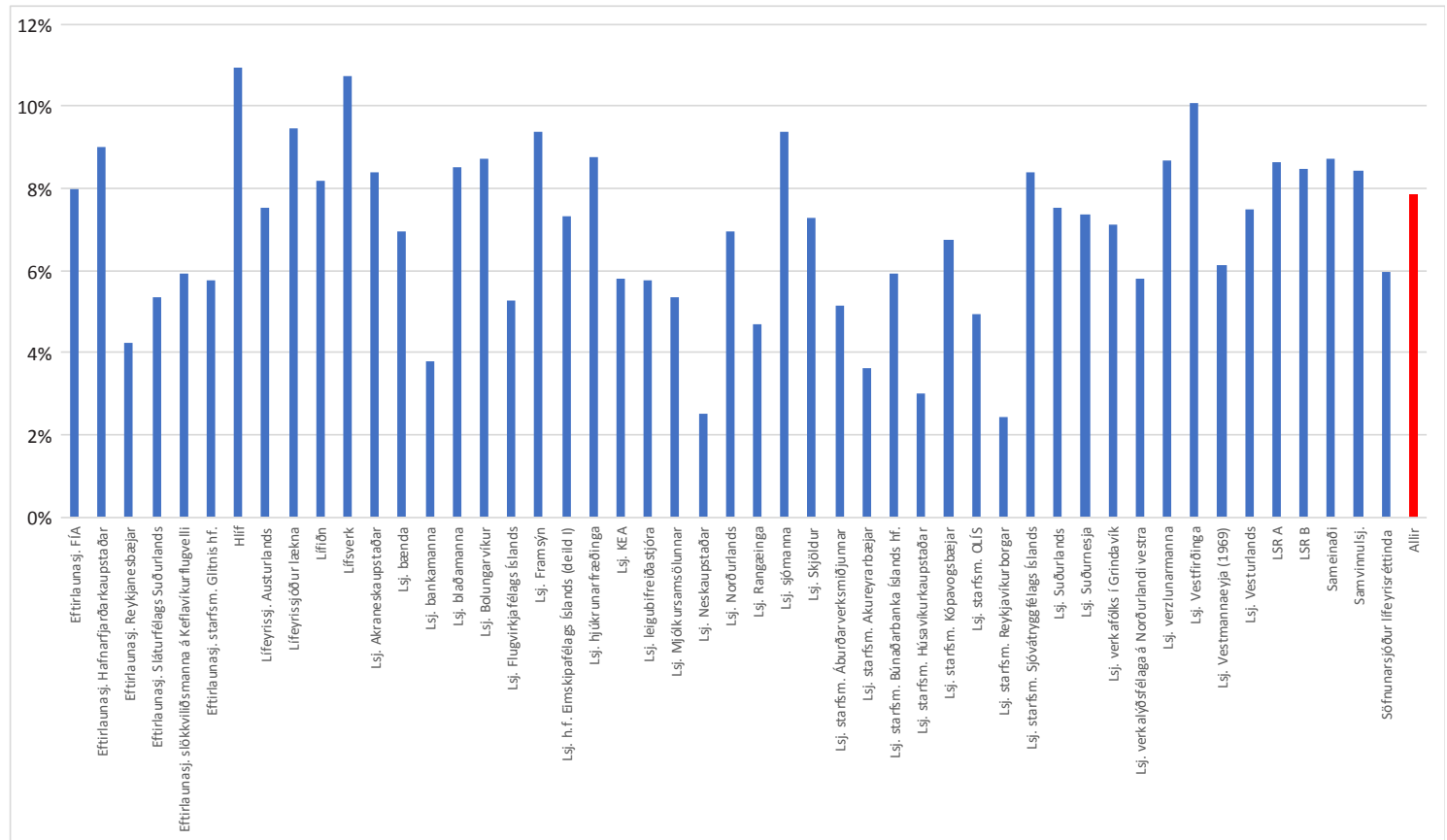

Mynd 10. Staðalfrávik ávöxtunar 49 sjóða sem voru starfandi árið 1997 tímabilið 1997-2017

Mynd 11 tengir saman staðalfrávik pað sem sýnt var á mynd 10 og raunávöxtun sem náðist tímabilið 1997-2017 og var sýnt á mynd 2. Sambandið virðist vera örlítið neikvætt. Línuleg aðhvarfsgreining með meðalávöxtun sem skýrða stærð og staðalfrávik sem skýristærð skilaði hallatölu upp á -0,16. Рað samsvarar pví að hvert auka prósentustig í staðalfráviki lækki meðalávöxtun um 0,16 prósentustig. M.ö.o., peir sjóðir sem tóku mesta áhættu skiluðu að öðru jöfnu lakari ávöxtun en peir sem tóku minni áhættu. Sambandið var tölfræðilega marktækt ( $t$-gildi $=-2,63, r^{2}=12,8 \%$ ). Pað kemur varla á óvart í ljósi afleitrar ávöxtunar áhæettusamra eigna í hruninu 2008.

18 Peir sjóðir sem meta hluta skuldabréfa á uppreiknaðri kaupkröfu í stað markaðsverðs ættu að öðru jöfnu að mælast með stöðugari ávöxtun en sjóðir sem meta allt skuldabréfasafnið á markaðsvirði. Hér er ekki leiðrétt fyrir hugsanlegum áhrifum pess og eru allar ávöxtunartölur reiknaðar út frá bókfærðu virði eigna. 


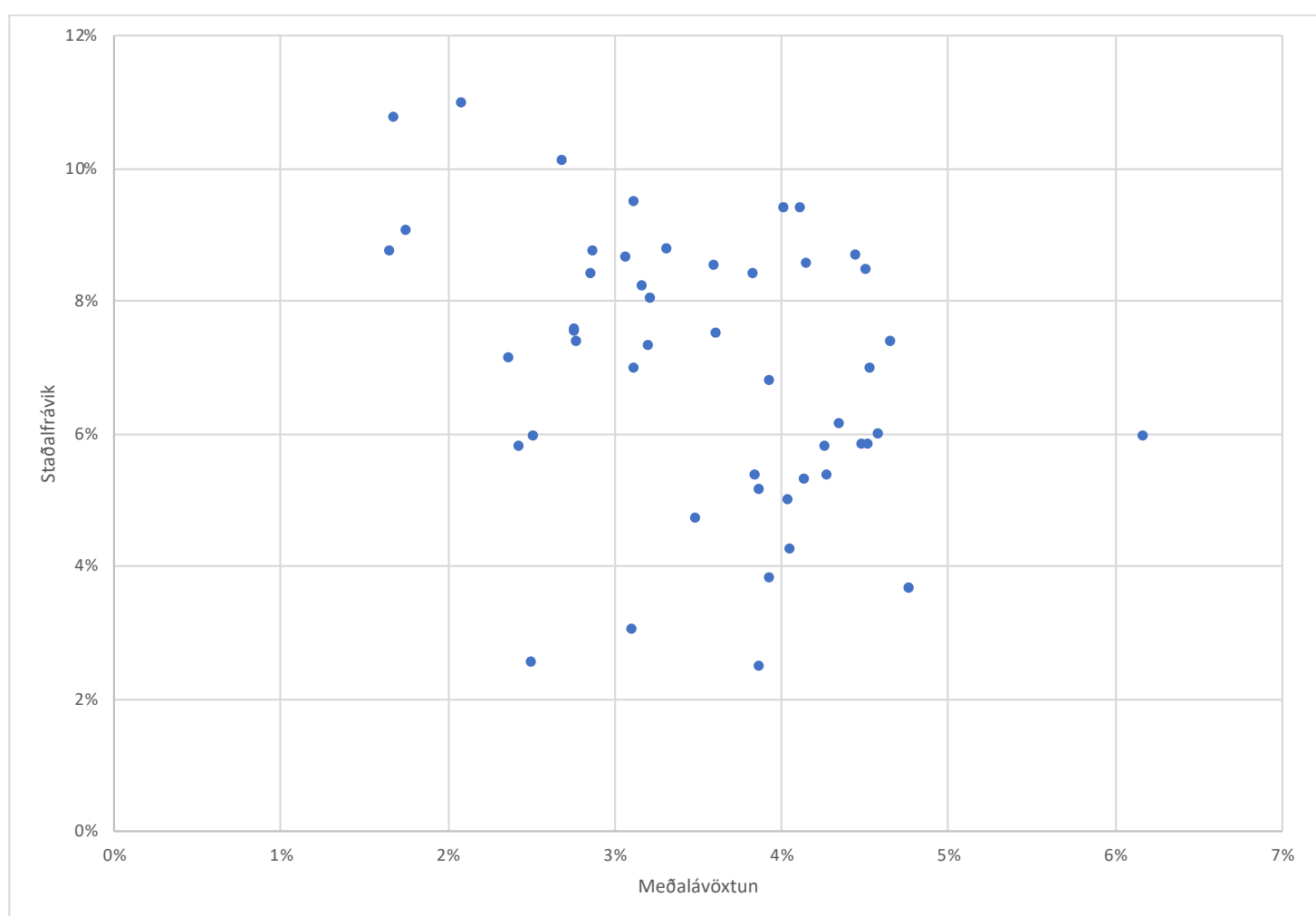

Mynd 11. Staðalfrávik og meðalávöxtun 49 sjóða og arftaka peirra 1997-2017

Pað er pó rétt að benda á að ekki er sjálfkrafa hægt að draga pá ályktun af fyrrgreindri niðurstöðu að lífeyrissjóðir eigi almennt að forðast áhættusamar eignir. Hér er einungis byggt á einu landi og einu tímabili með mjög sérstakri atburðarás. Erlendar rannsóknir benda fremur til pess að pegar til lengdar lætur séu eignir sem eru áhættusamar pegar horft er til skamms tíma, t.d. hlutabréf, eðlileg fjárfesting fyrir langtímafjárfesta, skili hærri meðalávöxtun og jafnvel með minni áhættu (Mehra og Prescott, 1985).

Sú staðreynd að lífeyriskerfið sem heild náði aðeins lakari ávöxtun en samsvarar áhættulausum vöxtum pýðir að margir algengir mælikvarðar á árangur í eignastýringu nýtast lítt við að meta árangurinn. Sá algengasti, svokallað hlutfall Sharpe (e. Sharpe ratio), mælir ávöxtun umfram áhættulausa vexti í hlutfalli við staðalfrávik ávöxtunar (Sharpe, 1966). Staðalfrávikið er pá notað sem mælikvarði á áhættu pannig að hlutfallið á að mæla áhættupóknun í hlutfalli við áhættu. Hlutfall Sharpe er einnig pekkt sem halli línu fjármagnsmarkaðarins (e. Capital Market Line). Pegar hlutfallið eða hallinn er mælt er oftast miðað við ávöxtun hlutabréfavísitölu. Hún á að endurspegla ávöxtun „markaðarins“. Frá peirri ávöxtun eru dregnir áhættulausir vextir, til að fá áhættupóknun markaðarins og síðan er deilt í áhættupóknunina með staðalfráviki ávöxtunar vísitölunnar. Niðurstöðuna má túlka sem markaðsverð áhættu, p.e. hvernig hægt er að fá hærri (vænta eða sögulega) ávöxtun með pví að sætta sig við meiri áhættu eins og hún mælist með staðalfráviki ávöxtunar.

Tafla 1. Sharpe hlutfall (halli línu fjármagnsmarkaðar) fyrir ýmis tímabil

\begin{tabular}{lcc}
\hline & Íslensk hlutabréf & Alheimshluta-bréfavísitala (MSCI) \\
\hline $1987-2017$ & $-0,035$ & 0,021 \\
$1993-2017$ & $-0,142$ & 0,112 \\
$1997-2017$ & $-0,252$ & 0,036 \\
$1997-2007$ & 0,342 & $-0,052$ \\
$2009-2017$ & 0,031 & 0,385 \\
$2013-2017$ & 0,341 & 0,283 \\
\hline
\end{tabular}


Vandinn við að nota hlutfall Sharpe sem árangursmælikvarða fyrir pað tímabil sem hér er til skoðunar er að halli línu fjármagnsmarkaðar eins og hann er oftast mældur var neikvæður pegar tímabilið í heild er gert upp. Skýringin er vitaskuld hrun hlutabréfamarkaðarins 2007-2009. Tafla 1 dregur petta fram. Miðað er við meðalávöxtun innlendrar hlutabréfavísitölu ${ }^{19}$ umfram áhættulausa verðtryggða vexti sem áhættupóknun og staðalfrávik ávöxtunar sem áhættumælikvarða. Jafnframt er sambærilegt hlutfall reiknað fyrir tiltekna heimsvísitölu hlutabréfa (MSCI World Index) í krónum. Sharpe hlutfallið fyrir heimsvísitöluna (mælt miðað við ávöxtun í krónum og áhættulausa vexti í krónum) var jákvætt fyrir tímabilið 1997-2017. Раð pýðir að búast má við að erlendi hluti hlutabréfasafns sjóðanna hafi skilað peim jákvæðri áhættupóknun pótt sá innlendi hafi skilað neikvæðri áhættupóknun. ${ }^{20}$

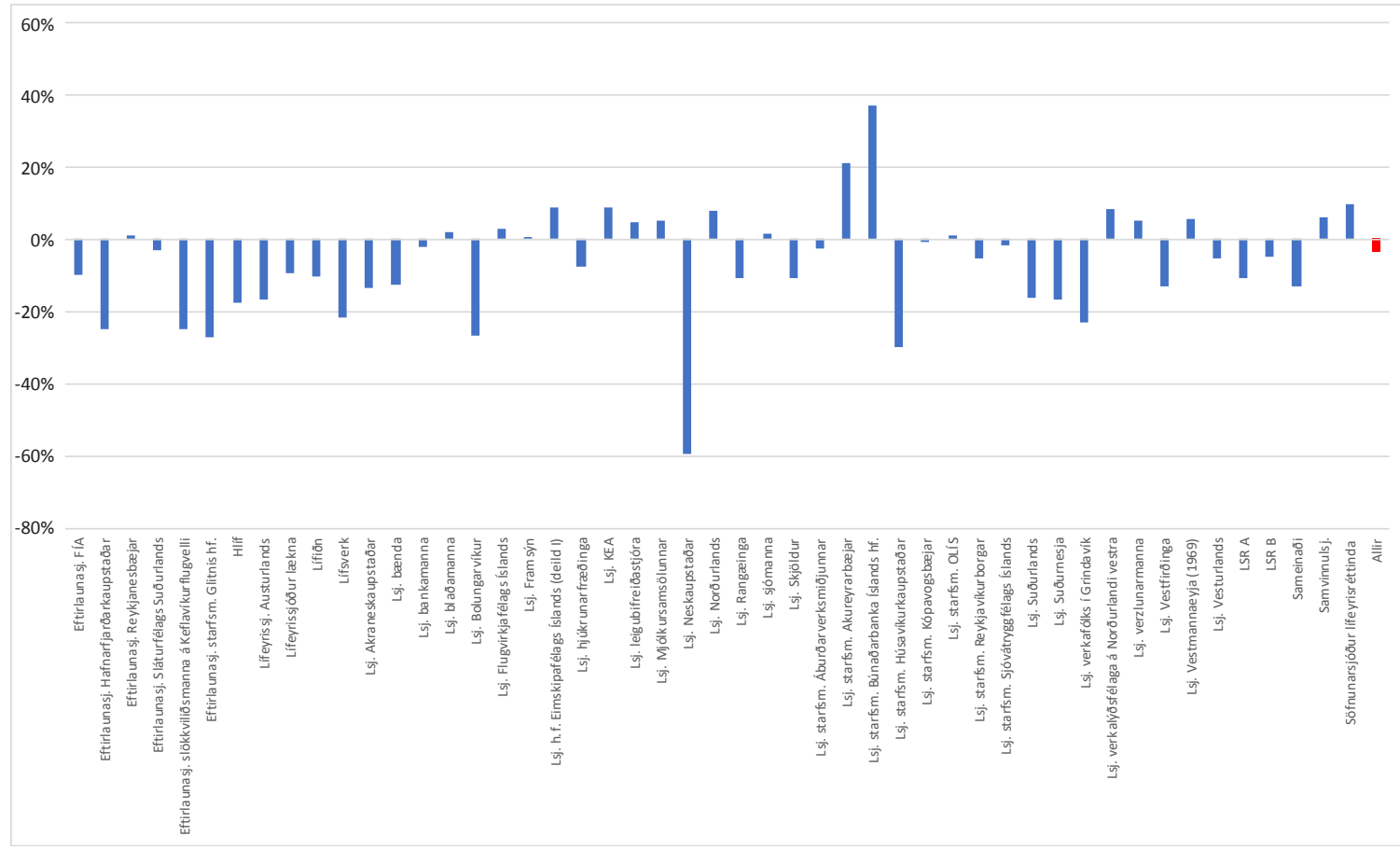

Mynd 12. Sharpe hlutföll 49 upphaflegra sjóða og arftaka peirra fyrir tímabilið 1997-2017

Mynd 12 sýnir Sharpe hlutfall upphaflegra sjóða og arftaka peirra fyrir allt tímabilið sem verið er að skoða. Eins og sjá má ná einungis 18 af 49 sjóðum að vera með jákvætt hlutfall, p.e. peir náðu hærri meðalávöxtun en sem nam áhættulausum vöxtum.

Pá sýnir mynd 13 Sharpe hlutföllin fyrir árin eftir hrun, p.e. 2009-2017. Á pví tímabili náðu allir sjóðirnir betri ávöxtun en áhættulausum vöxtum, p.e. voru með jákvæða áhættupóknun. Skýringarinnar má m.a. leita í töflu 1 en par má sjá að bæði innlend og erlend hlutabréf skiluðu jákvæðri áhættupóknun að jafnaði á tímabilinu.

19 Hlutabréfavísitalan er með arði (e. total return). Fyrstu árin er miðað við HMARK vísitöluna að viðbættum áætluðum arðgreiðslum (HMARK vísitalan var eingöngu birt sem verðvísitala) en eftir ársbyrjun 1993 vísitölur Kauphallar Íslands, fram að árslokum 2008 ICEX-15 TR en frá og með ársbyrjun 2009 OMX 8 GI.

20 Pótt meðalávöxtun innlendra hlutabréfa hafi pegar á heildina er litið verið neikvæð 1997-2017 pá geta bréfin engu að síður hafa skilað sumum fjárfestum, p.á m. lífeyrissjóðum, góðri ávöxtun. Hér skiptir vitaskuld höfuðmáli hvenær bréf voru keypt og hvenær seld. Peir sem keyptu bréf á tíunda áratugnum og fyrstu árin eftir aldamót en seldu vel fyrir hrun markaðarins náðu almennt að innleysa söluhagnað. Nokkuð skýrar vísbendingar eru um að рað hafi átt við um a.m.k. suma lífeyrissjóði en innlend hlutabréfaeign peirra óx hægar en sem nam ávöxtun markaðarins mestu bóluárin (2004-2006) sem bendir til pess að peir hafi selt meira en peir keyptu á peim tíma. 


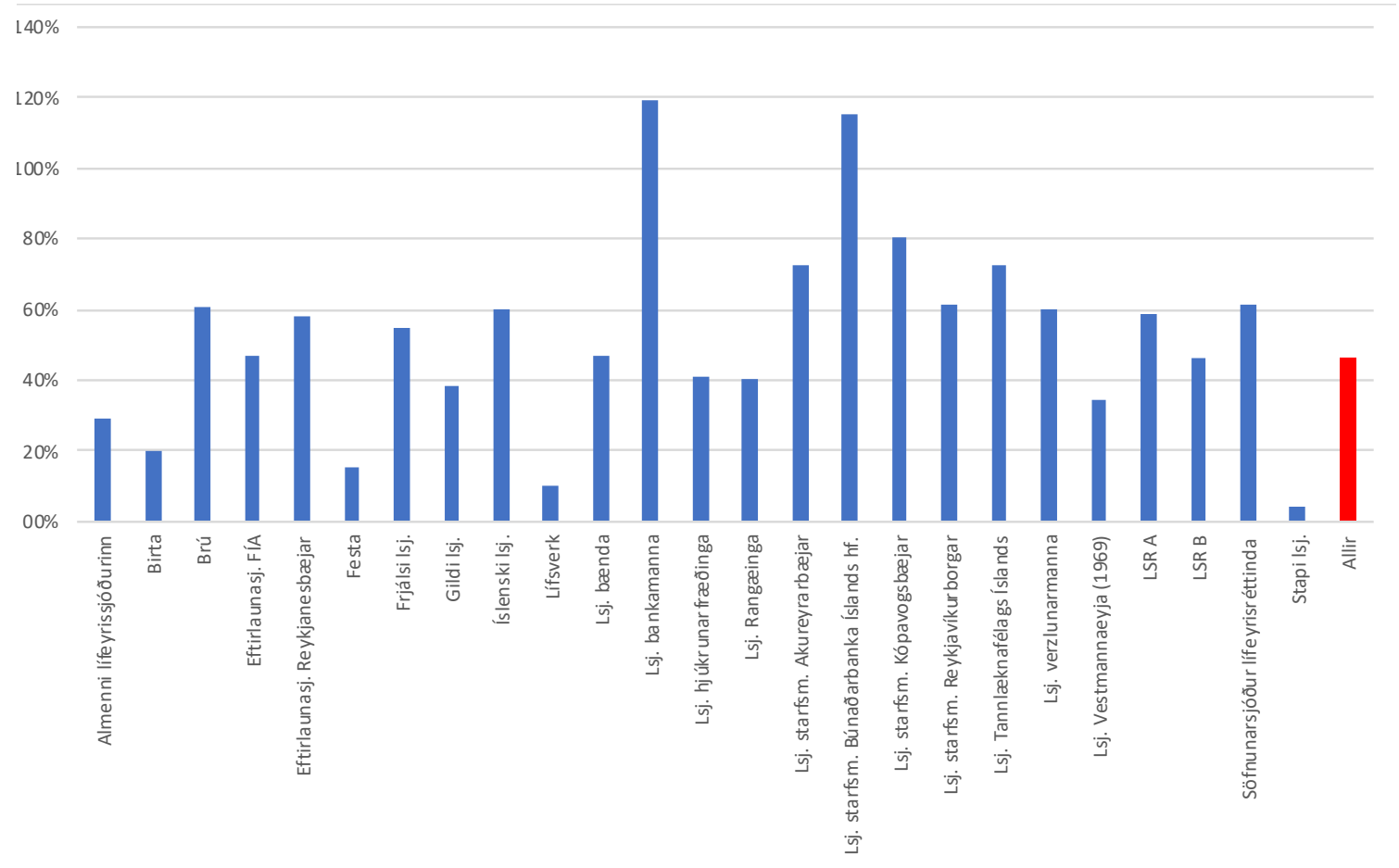

Mynd 13. Sharpe hlutföll fyrir 25 sjóði 2009-2017

Neikvætt Sharpe hlutfall eða neikvætt áhættuálag fyrir tímabilið í heild er fyrst og fremst afleiðing afleitrar ávöxtunar vegna hrunsins 2008. Hrunið er vitaskuld afar sérstakur viðburður. Við eðlilegri ástæður á mörkuðum hafa sjóðirnir notið jákvæðs áhættuálags flest ár og pegar meðaltal nokkurra ára er skoðað.

Sem fyrr segir er erfitt að reikna út eðlilegt viðmið fyrir ávöxtun lífeyrissjóðanna af ýmsum ástæðum. Ekki eru til góðar mælingar á ávöxtun sumra peirra eignaflokka sem hafa vegið pungt í eignasöfnum sjóðanna, p.á m. innlendra fyrirtækjaskuldabréfa og sjóðfélagalána. Pví verður hér einungis stillt upp mjög einföldu viðmiði sem byggir í grunninn á hugmyndinni um línu fjármagnsmarkaðar og tvískiptingarkenningunni (e. Two Fund Separation Theorem ${ }^{21}$ ) sem býr að baki henni. Verður pví miðað í grunninn við tvo eignaflokka, p.e. áhættulausar eignir (og ávöxtun peirra metin eins og áður) og áhættusamar eignir. Viðmiðunarávöxtun síðari flokksins verður metin út frá ávöxtun innlendra hlutabréfa annars vegar og alpjóðlegra hlutabréfa hins vegar, sbr. umfjöllun um töflu 1. Pannig verður síðari flokkurinn vegið meðaltal af ávöxtun tvenns konar eigna. Vogtölurnar eru fengnar frá yfirliti Seðlabanka Íslands um eignasöfn lífeyrissjóða. Nánar tiltekið verður vægi innlendu hlutabréfavísitölunnar reiknað út frá vægi eignaflokkarins „innlend hlutabréf og hlutdeildarskírteini“ og alpjóðlegu hlutabréfavísitölunnar út frá vægi erlendra eigna. Í pessu felst viss einföldun pví að innlendu hlutdeildarskírteinin hafa að einhverju marki verið gefin út af skuldabréfasjóðum eða blönduðum sjóðum en ekki hreinum hlutabréfasjóðum. Pví er vægi innlendra hlutabréfa væntanlega aðeins ofmetið. Vægi fyrir tiltekið ár er alltaf reiknað út frá eignastöðu í lok næsta árs á undan. Jafna (7) sýnir útreikning viðmiðsins.

$$
r_{t}^{B}=\frac{W_{t-1}^{I H}}{W_{t-1}} \cdot r_{t}^{i H}+\frac{W_{t-1}^{E H}}{W_{t-1}} \cdot r_{t}^{E H}+\frac{W_{t-1}-W_{t-1}^{I H}-W_{t-1}^{E H}}{W_{t-1}} \cdot r_{t}^{f}
$$


Hér er $r^{B}$ ávöxtun viðmiðs, $W^{i H}$ eru innlend hlutabréf, $W^{E H}$ eru erlend hlutabréf og $r^{f}$ áhættulausir vextir. Ávöxtun viðmiðsins er pví vegið meðaltal af ávöxtun priggja eignaflokka, innlendra hlutabréfa, erlendra hlutabréfa og ",alls annars“ sem reiknað er með að nái áhæettulausum íslenskum vöxtum.

Mynd 14 sýnir annars vegar ávöxtun samtryggingarsjóða sem heildar og hins vegar ávöxtun viðmiðsins. Eins og sjá má skýrir viðmiðið mjög vel ávöxtun sjóðanna. ${ }^{22}$ Pað má túlka pannig að sjóðirnir hafi yfirleitt náð peirri ávöxtun sem vænta mátti í ljósi pess sem helstu eignaflokkar skiluðu og í ljósi hlutfallslegs vægis hvers eignaflokks í fjárfestingum sjóðanna. Meðalávöxtun sjóðanna (3,73\% m.v. bókfært verð og u.p.b. 3,92\% m.v. markaðsverð) er pó aðeins undir meðalávöxtun viðmiðs (4,30\%). Skýringin gæti að hluta legið í pví að viðmiðin eru án alls kostnaðar og pví að sjóðirnir töpuðu nokkru á eignaflokkum sem ekki er reiknað með í viðmiðinu, p.e. gengisvörnum og innlendum fyrirtækjaskuldabréfum. ${ }^{23}$ Hér skiptir m.a. máli að lífeyrissjóðir hafa ekki eingöngu kostnað af fjárfestingum og eignastýringu heldur einnig af útgreiðslu lífeyris, innheimtu iðgjalda o.fl. Að pví leyti eru ávöxtunartölurnar t.d. ekki samanburðarhæfar við ávöxtun verðbréfasjóða. Pegar horft er til einstakra ára má muninn einkum rekja til pess að sjóðirnir náðu ekki alveg viðmiðinu á mestu uppgangstímunum, 2003-2005 og töpuðu aðeins meira en sem nemur viðmiðinu 2008-2009. Onnur ár munaði mjög litlu á ávöxtun sjóðanna og viðmiðsins.

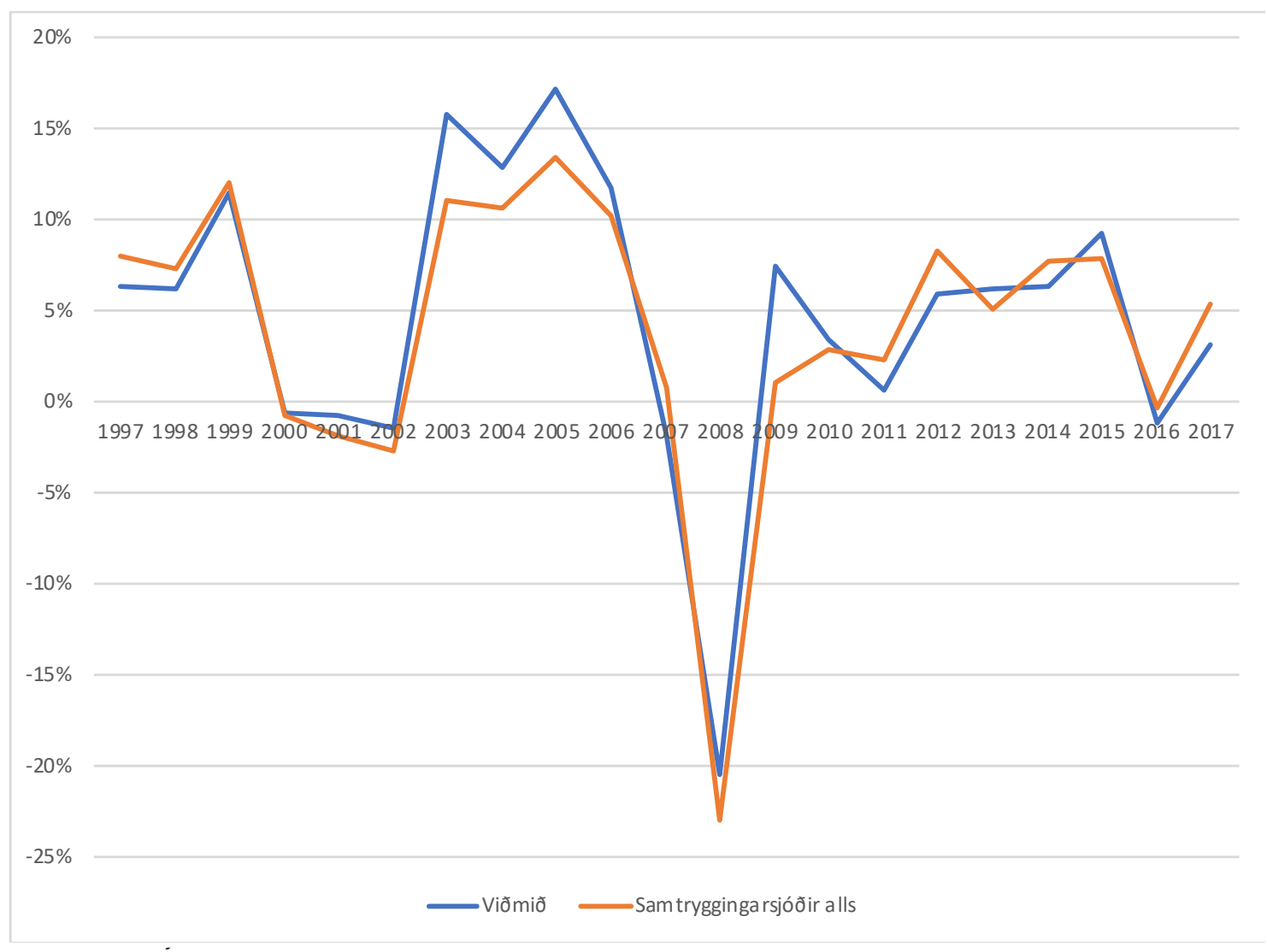

Mynd 14. Ávöxtun samtryggingarsjóða og viðmiðs 1997-2017

22 Línuleg aðhvarfsgreining með ávöxtun sjóðanna sem skýrða stærð og ávöxtun viðmiðs sem skýristærð gefur hallatölu 0,93 og $r^{2}$ 91,2\%. •að má túlka pannig að sveiflur í ávöxtun viðmiðs skýri 91,2\% af sveiflum í ávöxtun sjóðanna.

23 Gengisvarnir skiluðu hins vegar aukinni ávöxtun lífeyrissjóðanna áður en gengi krónunnar tók að falla síðla árs 2007. Meðan gengi krónunnar var tiltölulega stöðugt skiluðu varnirnar tekjum í samræmi við vaxtamun milli íslensku krónunnar og peirra erlendu mynta sem miðað var við í samningum um gengisvarnir. Hvorki er tekið tillit til pessa í útreikningi á ávöxtun viðmiðs né taps á vörnunum eftir að gengi krónunnar tók að falla hratt. 


\subsection{Samkvæmni}

Eitt af pví sem hefur verið rannsakað í paula í eignastýringu er hvort árangur á tilteknu tímabili hafi forspárgildi fyrir framtíðarárangur. T.d. er iðulega skoðað hvort verðbréfasjóðir sem skila góðum árangri (t.d. hærri en meðaltal eða hærri en viðmiðunarvísitala) á einu ári eru líklegri en aðrir til að skila góðum árangri árið á eftir. ${ }^{24}$ Svör við slíkum spurningum hafa ekki eingöngu fræðilegt gildi heldur einnig augljóst hagnýtt gildi fyrir pá sem geta valið sér sjóð. Hér verður ekki farið í viðamikla greiningu frá pessu sjónarhorni. Pó var skoðað hvort ávöxtun frá upphafi og framyfir hrun, p.e. 1997-2008, gefi vísbendingu um ávöxtun áranna eftir hrun, p.e. 2009-2017. Svar við peirri spurningu gæti t.d. varpað ljósi á hvort peir sem voru óánægðir með frammistöðu síns sjóðs í hruninu og aðdraganda pess hefðu haft ávinning af pví að skipta yfir í annan sjóð eftir hrun.

Mynd 15 sýnir ávöxtun 25 núverandi sjóða og forvera peirra, annars vegar tímabilið 1997-2008 og hins vegar eftir hrun, p.e. 2009-2017. Eins og sjá má er miklu minni munur á ávöxtun sjóðanna eftir hrun en fyrra tímabilið. Рað skipti pví minna máli í hvaða sjóð var greitt síðara tímabilið en pað fyrra. ${ }^{25} \mathrm{Mjög}$ veikt samband virtist á milli árangurs á fyrra tímabilinu og pví síðara. Línuleg aðhvarfsgreining benti til pess að ávöxtun peirra sem náðu góðum árangri fyrra tímabilið hefði að jafnaði verið aðeins hærri en hinna á síðara tímabilinu. Sambandið var pó ekki tölfræðilega marktækt $(t=0,64)$. Pegar einum útlaga var sleppt pá snerist formerkið við en sambandið var aftur ekki tölfræðilega marktækt $(t=-0,63)$. Einnig var sjóðunum skipt í tvo hópa á báđum tímabilum, pá sem náðu ávöxtun undir meðaltali og pá sem náðu ávöxtun yfir meðaltali. 12 af 25 sjóðum færðu sig á milli hópa á milli tímabila. Раð bendir til pess að ávöxtun yfir (eða undir) meðaltali á fyrra tímabilinu skýri ekki ávöxtun yfir (eða undir) meðaltali á pví síðara. M.ö.o. árangur í fortíð gefur enga vísbendingu um ávöxtun í framtíð, a.m.k. ekki miðað við árangur á pessum tveimur tímabilum. Рað virðist pví gagnslítið að velja lífeyrissjóð út frá fortíðarávöxtun hans.

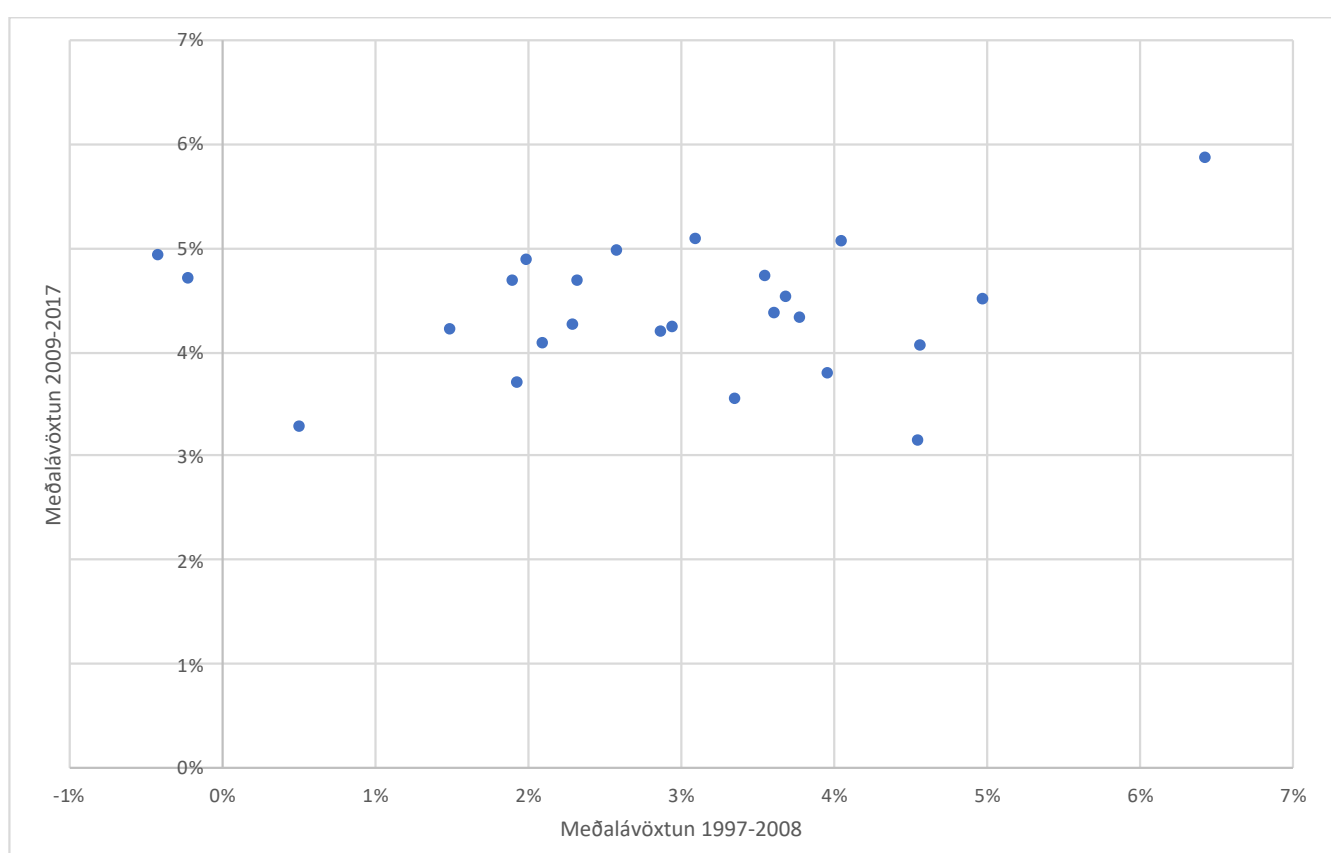

Mynd 15. Ávöxtun í hruni og aðdraganda pess (1997-2008) og ávöxtun eftir hrun (20092017)

25 núverandi sjóðir og forverar peirra. Miðað er við bókfært verð eigna.

24 Dæmi um innlenda rannsókn er (Gylfi Magnússon, Haukur C. Benediktsson og Kári Sigurðsson, 2010). Par má einnig sjá ítarlegri umfjöllun um aðferðafræði við slíkar rannsóknir.

25 Hér er sem fyrr horft framhjá öðrum páttum eins og t.d. hugsanlegum mun á lýðfræðilegum breytum milli sjóða. 


\section{3 Áhættudreifing sjóðfélaga}

Eitt af pví sem blasir við pegar ávöxtunartölurnar að framan eru skoðaðar er að verulegu máli getur skipt í hvaða lífeyrissjóði einstaklingur safnar réttindum. Ávöxtun sjóðanna hefur verið mjög misjöfn og mikill munur á pví hve margar krónur hver sjóður getur greitt í lífeyri fyrir hverja krónu sem greiddar hafa verið til hans sem iðgjöld. Í ljósi pessa var skoðað hvernig líkindadreifing ávöxtunar tiltekinnar upphæðar sem greidd var í iðgjöld í upphafi árs 1997 hefði verið miðað við að hún hefði öll farið í einn sjóð eða henni í staðinn skipt á tvo eða tíu sjóði. Slík greining ætti að gefa vísbendingu um kosti pess að byggja upp réttindi í fleiri en einum sjóði. Núverandi lífeyriskerfi býður í fæstum tilfellum upp á pað, p.e. nema launpegi hafi val um í hvaða sjóð iðgjöld hans renna eða ef hann skiptir um lífeyrissjóð vegna pess að hann skiptir um starf og verkalýðsfélag.

Mynd 16 sýnir reiknaða líkindadreifingu ávöxtunar m.v. sögulega ávöxtun 49 sjóða og arftaka peirra 1997-2017 og að sjóðfélagi velji ýmist einn, tvo eða tíu sjóði til að greiða í, jafnmikið í hvern, í upphafi tímabilsins. Eins og sjá má verður líkindadreifingin sífellt péttari, p.e. áhætta minnkar, eftir pví sem iðgjaldinu er dreift á fleiri sjóði. Pað kemur vitaskuld ekki á óvart, hér er um einfalda áhættudreifingu að ræða. Eftir pví sem fylgni í ávöxtun er minni milli sjóða, ${ }^{26}$ peim mun meiri áhættudreifing næst fram.

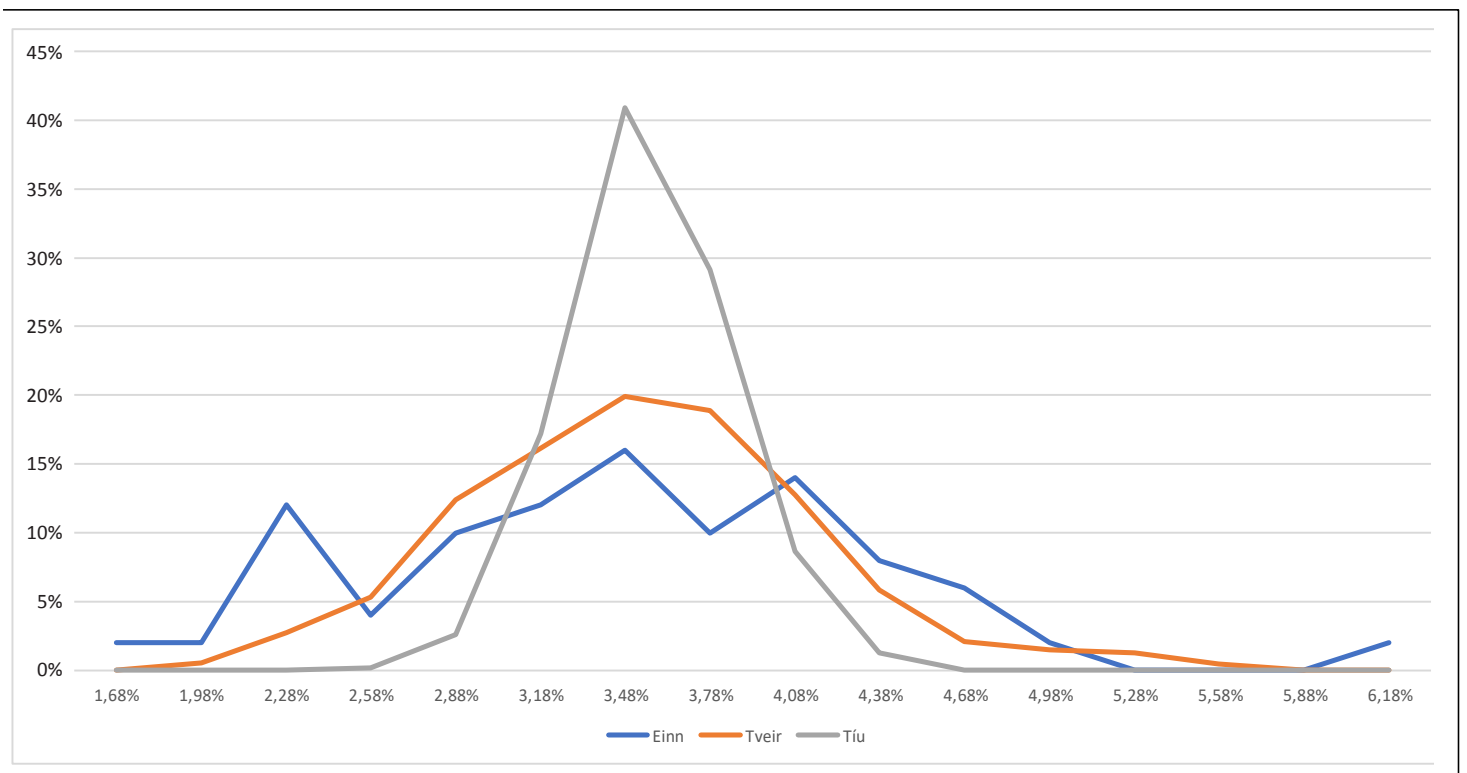

Mynd 16. Líkindadreifing ávöxtunar m.v. að velja einn, tvo eða tíu sjóði af 49 af handahófi í ársbyrjun 1997

Pessi einfalda niðurstaða dregur fram einn augljósan galla á íslenska lífeyriskerfinu, p.e. fólki er gert erfitt fyrir um að dreifa réttindum sínum á fleiri en einn sjóð. Рað væri pó augljós áhæettudreifing.

Pótt pessi rannsókn hafi fyrst og fremst skoðað eignahlið lífeyrissjóðanna verður einnig að víkja stuttlega að áhættu sem á uppruna sinn á hinni hlið efnahagsreiknings sjóðanna, p.e. réttindamegin. Vegna pess að samtryggingarkerfið og sjóðir pess eru starfstengdir og starfstéttir mjög ólíkar pá getur verið verulegur munur milli sjóða hvað varðar lífs- og örorkulíkur sjóðfélaganna. Petta býr til áhættu fyrir sjóðfélaga, til viðbótar við pá óvissu um ávöxtun sem er aðalumfjöllunarefni greinarinnar.

Skýrasta dæmið um petta er kynjaskipting, sem er mjög ólík milli sjóða. Hún skiptir máli pví að lífslíkur kynjanna eru mjög misjafnar. Kona sem náði algengum eftirlaunaaldri, 67

26 Fylgnin var almennt mjög há milli sjóða. Reiknuð var fylgni ávöxtunar hvers sjóðs við ávöxtun sjóðanna sem heildar. Var hún að meðaltali 0,90 og lægst 0,37. Рað dregur úr virkni áhættudreifingar sem næst með pví að greiða í fleiri en einn sjóð en hún getur engu að síður verið töluverð. 
árum, árið 2017 gat vænst pess að lifa í 19,3 ár eftir pað en karl í 17,4 ár. (Hagstofa Íslands, e.d.). Petta hefur pau augljósu áhrif að lífeyrissjóður sem í væru eingöngu konur pyrfti að dreifa greiðslum á fleiri ár en sjóður sem í væru eingöngu karlar. Eftirlaunin yrðu að vísu sambærileg en dreifðust á fleiri ár og væru lægri á hverju ári hjá konunum. ${ }^{27}$ Par eð kynjahlutföll eru mjög ólík milli sjóða verða pví líkleg árleg eftirlaun pað líka. Karl sem greiðir í sjóð par sem aðrir sjóðfélagar eru einkum konur fær í heildina lægri eftirlaun og lægri greiðslur á hverju ári en ef hann hefði greitt í sjóð par sem einkum eru karlar. Sömuleiðis myndi kona njóta góðs af pví að greiða í sjóð par sem aðrir sjóðfélagar eru einkum karlar. ${ }^{28}$

Að auki er örorkubyrði mjög ólík milli sjóða, fyrst og fremst vegna pess að örorkutíðni er ólík milli starfstétta og kynja. Pótt ríkið veiti nokkrum fjármunum til að jafna örorkubyrði lífeyrissjóða pá gerir petta stöðu sjóðanna um margt ólíka og í pví felst áhætta fyrir sjóðfélaga. ${ }^{29}$

Mynd 17 sýnir hlut kvenna í annars vegar iðgjaldagreiðslum og hins vegar lífeyrisgreiðslum samtryggingarsjóða árið 2017. Eins og sjá má er hlutfallið mjög misjafnt. Að meðaltali greiddu konur 41,7\% iðgjalda og fengu 43,3\% lífeyrisgreiðslna petta ár en hlutföllin fara alveg frá pví að vera 0 og upp í 99,4\% í einstökum sjóðum. P.e. sumir sjóðir eru nánast hreinir kvennasjóðir og aðrir nánast hreinir karlasjóðir. Athyglisvert er að sjóðir sem eru ekki tengdir tilteknum verkalýðsfélögum eru almennt með lágt hlutfall kvenna meðal sjóðfélaga.

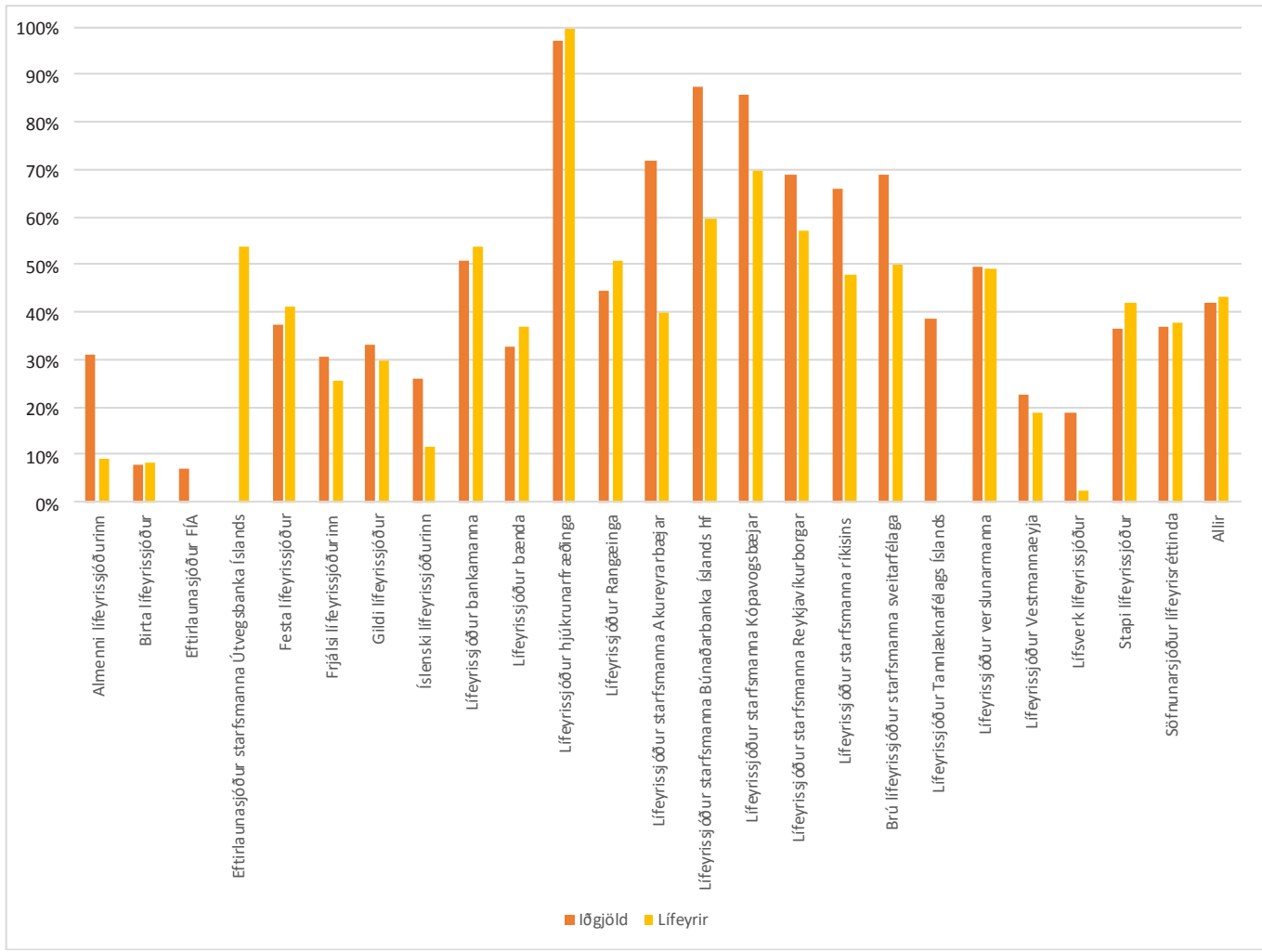

Mynd 17. Hlutur kvenna í iðgjöldum og lífeyri árið 2017 eftir sjóðum

27 Í umfjölluninni um kynjahlutföll í sjóðum er miðað við eftirlaun í hlutfalli við iðgjöld. Vegna launamunar kynjanna hafa iðgjöld kvenna að jafnaði verið lægri en karla. Áhrif pess eru ekki skoðuð hér.

28 Athyglisvert er að í lögum um lífeyrissjóði (129/1997) er í 14. gr. heimilað að skipta uppsöfnuðum ellilífeyrisréttindum milli hjóna. Við uppskiptinguna skal pess pó gætt að heildarskuldbinding viðkomandi lífeyrissjóðs aukist ekki vegna pessa. að pýðir í reynd að tekið er tillit til pess við skiptinguna að lífslíkur kynjanna eru ekki pær sömu. Pað er undantekning frá peirri meginreglu að réttindaávinnsla í lífeyriskerfinu taki ekki tillit til mismunandi lífslíka kynjanna.

29 Með lagabreytingu árið 2006 (lög 177/2006) var ákveðið að greiða lífeyrissjóðum hluta tryggingargjalds, p.e. 0,325\% af gjaldstofni, til að jafna örorkubyrði sjóðanna og hefur pað verið gert frá árinu 2007. Í fjárlögum ársins 2018 er gert ráð fyrir 4.527 milljónum króna til að jafna örorkubyrði almennra lífeyrissjóða. 
Mynd 18 sýnir svo skiptingu sjóðfélaga í annars vegar pá sem piggja örorkulífeyri og hins vegar pá sem annað hvort greiða iðgjöld (virkir) eða piggja ellilífeyri. Dreifingin er mjög misjöfn milli sjóða. Að meðaltali er hlutfallið 7,2\% en pað fer alveg niður í 0 og upp í rúm $15 \%$.

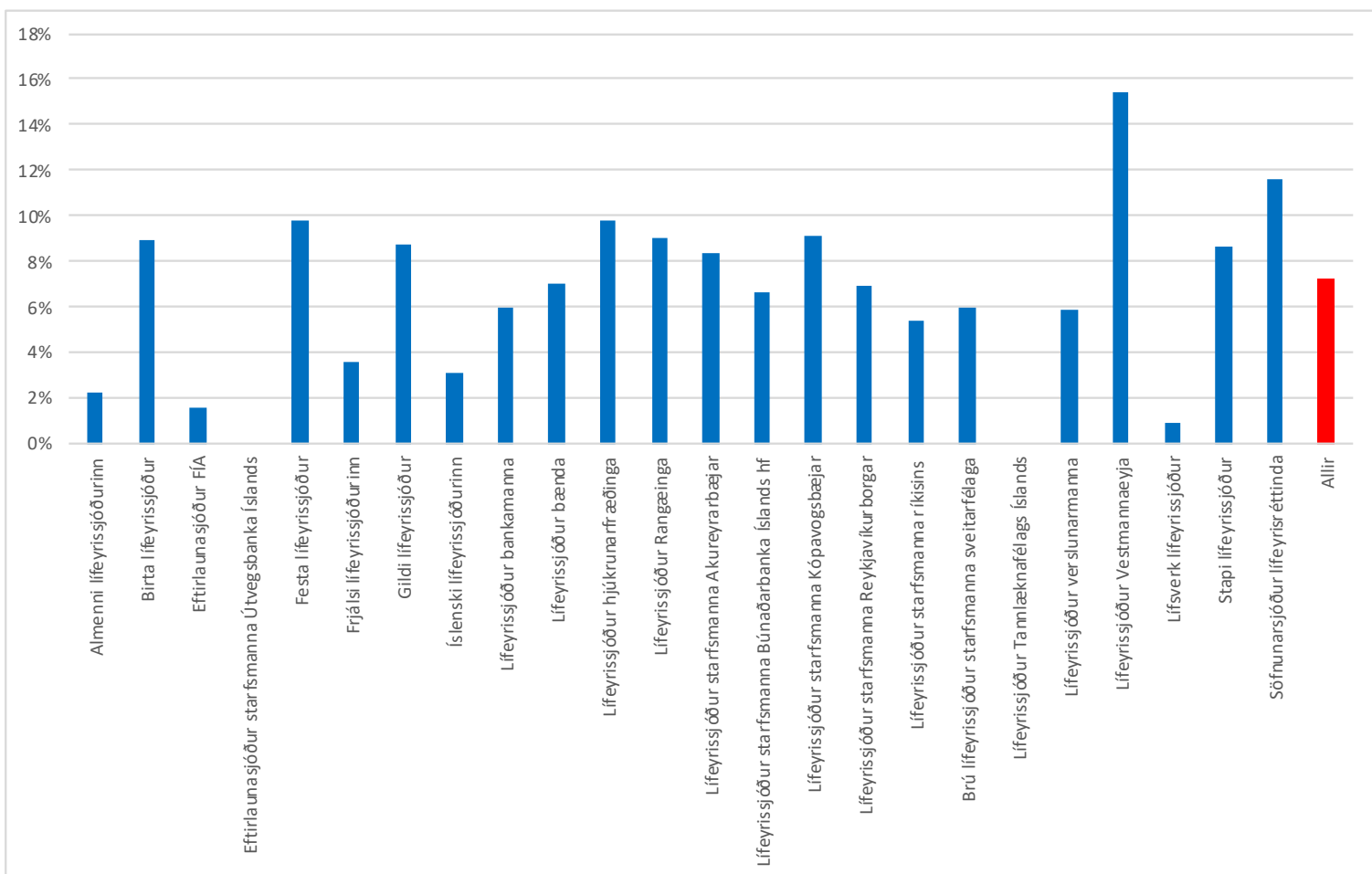

Mynd 18. Fjöldi piggjenda örorkulífeyris í hlutfalli við pá sem greiða iðgjöld eða piggja ellilífeyri eftir sjóðum

Myndir 17 og 18 draga fram einn veikleika íslenska lífeyriskerfisins. Vegna starfstengingarinnar eru hóparnir að baki hverjum sjóði mjög ólíkir. Рað hefur áhrif á getu sjóðanna til að greiða lífeyri og býr pví nánast sjálfkrafa til mismunun í lífeyri milli stétta og kynja, til viðbótar við pá mismunun sem ólík ávöxtun eigna býr til.

Pá er pað jafnframt galli við uppbyggingu kerfisins að allir sjóðfélagar í tilteknum lífeyrissjóði standa frammi fyrir sömu áhættu vegna ávöxtunar eigna, óháð áhættupoli peirra. Sérstaklega er óeðlilegt að lífeyrispegar og peir sem eiga stutt eftir að töku lífeyris standi frammi fyrir sömu áhættu og yngstu sjóðfélagarnir. Síðari hópurinn hefur verulegt svigrúm til að mæta áföllum, t.d. með hærri iðgjöldum síðar eða með pví að seinka töku eftirlauna, og nýtur auk pess tilhneigingar verðs á eignamörkuðum til endurhvarfs til miðjunnar (e. reversal to the mean). Lífeyrispegar geta hins vegar illa varið sig áföllum. Nokkrir lífeyrissjóðir gerðu tilraunir á pví tímabili sem hér er til skoðunar með deildaskiptingu til að taka á pessum vanda en hurfu frá henni síðar.

\section{Lokaord}

Íslenska lífeyriskerfið hefur pegar á heildina er litið náð ásættanlegri ávöxtun á pví tímabili sem hér er til skoðunar. Ávöxtunin er nokkurn veginn í takti við pað sem peir eignaflokkar sem sjóðirnir fjárfesta einkum í hafa skilað og örlítið yfir ávöxtunarviðmiði sjóðanna. E.t.v. má líta svo á að kerfið hafi lifað hrunið af. Рað er vitaskuld nokkuð afrek í ljósi pess hvað gekk á. Meðaltalið felur hins vegar að pað er verulegur munur á ávöxtun á milli sjóða. Hann pýðir óhjákvæmilega að einnig verður munur á peim lífeyri sem sjóðirnir geta greitt og par með lífskjörum sjóðfélaga. Jafnframt er verulegur munur á eiginleikum peirra hópa sem standa að baki hverjum lífeyrissjóði, p.á m. hvað varðar lífs- og örorkulíkur. Petta 
mun á sama hátt gera pað að verkum að munur verður á peim lífeyri sem sjóðfélagi getur vænst eftir lífeyrissjóðum. Kerfið býr pví til eins konar lífskjarahappdrætti. Pað er stór og augljós galli á annars að mörgu leyti vel heppnuðu kerfi.

Hér verða ekki lagðar fram útfærðar tillögur til úrbóta. Fræðilega séð væri pað pó tiltölulega einfalt, p.e. með pví að dreifa iðgjöldum hvers launpega á fleiri en einn sjóð. Pá væri kostur að binda sjóðina ekki við tilteknar starfsstéttir og jafna mun á kynjahlutföllum og örorkulíkum milli sjóða. Рað gæti hins vegar verið pólitískt flókin breyting enda sjóðirnir nátengdir verkalýðshreyfingunni og kjarasamningum.

Hér verður engu spáð um framtíðarávöxtun sjóðanna. Pó skal bent á að mjög varhugavert er að gera ráð fyrir að peir muni ná svipaðri ávöxtun og pau ár sem hér eru til skoðunar, a.m.k. ekki á skuldabréf. Skiptir par m.a. máli að raunvextir hafa lækkað verulega og voru í ársbyrjun 2018 rétt um priðjungur pess sem peir voru í ársbyrjun 1997. Рað var vitaskuld ekki erfitt að ná ásættanlegri ávöxtun án áhættu meðan áhættulausir vextir voru talsvert hærri en ávöxtunarviðmið sjóðanna, líkt og í upphafi pess tímabils sem hér er skoðað. Hærri iðgjaldgreiðslur og par með aukinn pjóðhagslegur sparnaður mun að öðru jöfnu líklega valda enn frekari lækkun vaxtanna á næstu árum að öðru óbreyttu. Á móti kemur pó að líklega geta sjóðirnir vænst einhvers áhættuálags ofan á áhættulausa raunvexti ólíkt pví sem varð raunin pegar upp var staðið árin 1997-2017. ${ }^{30}$ Pað er hins vegar fyrir utan efni pessarar greinar að skoða pað nánar.

\section{Heimildir}

Ásgeir Jónsson og Alexander Freyr Einarsson. (2018). Framtak við endurreisn. Reykjavík: Auðfræðasetur. Sótt af http://audfraedi.is/library/Skrar/Framtak\%20við\%20endurreisn.pdf.

Ásgeir Jónsson og Hersir Sigurgeirsson. (2014). Áhættudreifing eða einangrun? Um tengsl lífeyrissparnaðar, greiðslujafnaðar og erlendra fjárfestinga. Reykjavík: Landssamtök lífeyrissjóða. Sótt af https://www.lifeyrismal.is/is/frettir/ahaettudreifing-eda-einangrun.

Elton, E. J., Gruber, M. J. og Blake, C. R. (1996). Survivor Bias and Mutul Fund Performance. The Review of Financial Studies, 9(4), 1097-1120.

FME. (2014). Nægjanleiki lífeyrissparnaðar: Rannsókn á Íslandi. Reykjavík: Fjármálaeftirlitið. Sótt af https://www. fme.is/media/frettir/Naegjanleiki-lifeyrissparnadar-4febr15.pdf

Gylfi Magnússon, Haukur C. Benediktsson og Kári Sigurðsson. (2010). Er samkvæmni í árangri verðbréfasjóða? Tímarit um viðskipti og efnahagsmál, 7(1), 97-114. https://doi.org/10.24122/tve.a.2010.7.1.6.

Gylfi Magnússon. (2013). Söguleg ávöxtun íslenskra lífeyrissjóða. Í Ingjaldur Hannibalsson (ritstj.), Rannsóknir i félagsvísindum XIV. Reykjavík: Félagsvísindastofnun. Sótt af http://hdl.handle.net/1946/16798

Gylfi Magnússon, Hersir Sigurgeirsson, Pórey S. Pórðardóttir, Ólafur Sigurðsson og Fjóla Agnarsdóttir. (2017). Skýrsla starfshóps um erlendar fjárfestingar lífeyrissjóða. Reykjavík: Efnahags- og fjármálaráðuneytið. Sótt af https://www.stjornarradid.is/media/fjarmalaraduneyti-media/media/frettatengt2016/Skyrsla-starfshopsum-erlendar-fjarfestingar-lifeyrissjoda.pdf.

Hrafn Bragason, Héðinn Eyjólfsson og Guðmundur Heiðar Frímannsson. (2012). Úttekt á fjárfestingarstefnu, ákvarðanatöku og lagalegu umhverfi lífeyrissjóðanna i aðdraganda bankahrunsins 2008. Úttektarnefnd Landsamtaka lífeyrissjóða.

Kristíana Baldursdóttir. (2000). Eignir og ávöxtun lífeyrissjóða. Peningamál, 2000(3), 27-31.

Lífeyrissjóður bankamanna. (2008). Ársreikningur 2007.

Lífeyrissjóður starfsmanna Búnaðarbanka. (2009). Ársreikningur 2008.

Lífeyrissjóður starfsmanna Reykjavíkurborgar. (2009). Ársreikningur 2008.

Mehra, R. og Prescott, E. C. (1985). The Equity Premium: A Puzzle. Journal of Monetary Economics, 15, 145-161.

Piketty, T. (2013). Capital in the Twenty-first Century (Le Capital au XXIe siècle) (Pýð. Arthur Goldhammer). Cambridge: Harvard University Press.

Sharpe, W. (1966). Mutual Fund Performance. The Journal of Business, 39(1), 119-138.

Tobin, J. (1958). Liquidity preference as behavior towards risk. Review of Economic Studies, 25(1), 65-86.

Vísbending. (2016). Hvernig spörum við? Vísbending, 34(6), 1-2.

Enn fremur tölulegar upplýsingar frá FME (sjá https://www.fme.is/utgefid-efni/tolulegar-upplysingar/), Hagstofu Íslands, Seðlabanka Íslands, Tryggingastofnun og MSCI.

30 Рað liggur pó í hlutarins eðli að jafnvel pótt vænt áhættuálag (ex ante) sé jákvætt pá getur sögulegt áhættuálag (ex post) orðið neikvætt um lengri eða skemmri tíma í framtíðinni. 